\title{
WestVirginiaUniversity
}

THE RESEARCH REPOSITORY @ WVU

Graduate Theses, Dissertations, and Problem Reports

2017

\section{An Abridged Study}

\author{
Jacob Guzan
}

Follow this and additional works at: https://researchrepository.wvu.edu/etd

\section{Recommended Citation}

Guzan, Jacob, "An Abridged Study" (2017). Graduate Theses, Dissertations, and Problem Reports. 5727. https://researchrepository.wvu.edu/etd/5727

This Thesis is protected by copyright and/or related rights. It has been brought to you by the The Research Repository @ WVU with permission from the rights-holder(s). You are free to use this Thesis in any way that is permitted by the copyright and related rights legislation that applies to your use. For other uses you must obtain permission from the rights-holder(s) directly, unless additional rights are indicated by a Creative Commons license in the record and/ or on the work itself. This Thesis has been accepted for inclusion in WVU Graduate Theses, Dissertations, and Problem Reports collection by an authorized administrator of The Research Repository @ WVU. For more information, please contact researchrepository@mail.wvu.edu. 


\title{
AN ABRIDGED STUDY
}

\author{
Jacob Guzan
}

\author{
Thesis submitted \\ to the College of Creative Arts \\ at West Virginia University \\ in partial fulfillment of the requirements for the degree of \\ Master of Fine Arts in \\ Printmaking
}

\author{
Joseph Lupo, M.F.A., chair \\ Michael Sherwin, M.F.A. \\ Amy Schissel, M.F.A. \\ Gerald Habarth, M.F.A. \\ Department of Art and Design
}

Morgantown, West Virginia

2017

Keywords: Printmaking, Intaglio, Typology, Infrastructure, Functional Aesthetic Copyright 2017 Jacob Guzan 


\section{ABSTRACT \\ ANABRIDGED STUDY}

Jacob Guzan

This MFA thesis addresses work completed and presented in a thesis exhibition at West Virginia University, the conceptual underpinnings of this work, and the personal motivations for such conceptual lines of inquiry. Focusing on traditional fine art practices of drawing and intaglio printmaking, the accurate reproduction of reality is a strategy for changing the context in which utilitarian infrastructural objects are seen. The goal of this project is to shift infrastructure from "eyesore" status to a state of aesthetic appreciation. Through visual isolation, these objects are given the opportunity to stand as discrete and sublime forms. The objects cease to be interlopers, and become integral parts of the visual environment when reintroduced to their landscape. I ground the inquiry into these objects in a personal exploration of my own landscape. The work simultaneously addresses the objects being studied as well as the very act of studying them. 


\section{ACKNOWLEDGEMENTS}

I want to take this opportunity to thank the West Virginia University Faculty for having the faith in me to accept me as a graduate student and give me the opportunity to teach their students. In particular, I want to thank Joseph Lupo for guiding me through the trials and expectations of grad school, for being the best committee chair I could have hoped for, and for gently pushing me in the right direction when I was listless. I want to thank the other members of the faculty who contributed to the development of my work, specifically Michael Sherwin, Amy Schissel, Gerald Habarth, and Jason Lee for their critical input, encouragement, and unique perspectives. I want to thank my mother, Gale Thull, for encouraging me to pursue a career in the arts in the first place and for supporting me along the way.

I would be very much amiss to not mention and thank Michael Oliver for his photographic documentation of my work, Stephanie Alaniz for her colored pencils (which I'm sorry I used so thoroughly) and to Rachel Simpson, whose retro pencil sharpener gave me a sharp edge to work with. Lastly, I want to thank my loving girlfriend, Tessa Lee Martinez, who appeared halfway through my three years at WVU and at a time when I had lost all interest in my endeavors and showed me there were still things worth working for. 


\section{TABLE OF CONTENTS}

ACKTRACT




\section{MOTIVATIONS}

"Nothing is so fatal to the human mind as to suppose our views of science are ultimate; that there are no mysteries in nature; that our triumphs are complete; and that there are no new worlds to conquer."

Humphry Davy, lecture $1810^{1}$

As a child growing up in the suburbs of Chicago, I remember visiting many small nature preserves with my father. Often these nature preserves would include a pond or marsh. It was common for us to bring a net, and I remember clearly the act of thrusting that net into the murky water to drag up the contents. Peering into the net, I would see movement. Among the pieces of duckweed and other aquatic plants, was a treasure of little creatures: leopard frogs, tadpoles, whirligig beetles, water bugs, dragonfly and mayfly nymphs, crayfish, minnows, leaches, and a slew of other things with names I didn't know. Surely, someone somewhere was familiar with all these, knew their Latin names and characteristics. Their existence was not new to science, but it was new to me. Since that time, I've thought about the importance of those experiences, the importance of retaining that curiosity, and the importance of looking at the world around me as if it is newly discovered. As the world is mapped, the definitive texts written, and the frontier of what is unknown moves further and further away, I feel it is still important to retain a sense of curiosity and discovery in our surroundings, even in the most mundane forms and spaces. In my research and artwork, I am trying to do just that.

\footnotetext{
1 Richard Holmes, The age of wonder: how the romantic generation discovered the beauty and terror of science (New York, NY: Pantheon Books/Vintage Books, 2010), xiii.
} 


\section{THE NATURALIST}

Normally the fascination with observing the natural world is limited to exclude the manmade parts of it. To the naturalist, the manmade is seen as artificial, inauthentic, or simply separate from nature, but why? When a termite colony builds a mound, is this mound considered part of nature or is it termite-made? In reality, the monikers 'termite-made' or 'manmade' are not opposite of 'natural' but a subcategory of it. If manmade objects are a part of nature, then there is legitimacy in studying them as we study nature. In my art practice, I see myself playing the role of a naturalist of the artificial. My objective is to explore, observe, and present the visual existence of certain classes of objects, not to understand the intricacies of electrical systems and civil engineering. For a scientist, observation is a tool used to bring about the goal of understanding and determining facts. For an artist, observation itself can be the goal. To say that what I am doing is scientific would be a misnomer; what I am doing is observational.

\section{INFRASTRUCTURE}

Infrastructure represents a class of manmade objects made with little to no aesthetic consideration. With the exception of some decorated water towers and architecturally designed large bridges, infrastructure is a series of utilitarian objects that exist to serve a functional purpose. When any design attention is given to them, it is usually with the purpose of hiding them. There is a booming business built around disguising things like cell towers. They are turned into water towers, steeples, and crosses, or made to look like trees, palms, rocks, cactuses, and lampposts in the hope of utilizing an aesthetic more palatable to the general public. ${ }^{2}$ The reality is that we don't want to see elements of infrastructure. Out in the pastoral landscape, they are eyesores, interlopers, and undesirable outcrops of

\footnotetext{
2 Rachel Swaby, "The Art of Disguising Cellphone Towers," Gizmodo, May 12, 2011, , accessed January 17, 2017, https://gizmodo.com/5801212/the-art-of-disguising-cellphone-towers.
} 
electronic technology interrupting the way the scene 'should be. ${ }^{3}$ Even in our manmade architectural environment, many infrastructure objects are seen as unwanted visual pollution.

While I believe in blurring the distinction between 'manmade' and 'natural', to argue there is no difference between the two is a ham-fisted assertion. So it is important to expound on the specifics of their similarities and differences, and where infrastructure fits into this spectrum. Organisms within the natural world, especially plants, have forms completely dictated by function. The size of a leaf, a branch, or the height of a tree are all the result of the need for sunlight, the requirements of resisting wind, the availability of nutrients, etcetera. Form is a response to the organisms' environment. This functionality, and nature's success in reproducing itself, continually effects the organisms' design. No leaf is a certain shape because of the positive aesthetic properties of such a shape, only the functionality and fitness of it. In this way, an organism is a refection of its environment and its role in that environment. The honesty and authenticity of such a design process should be unimpeachable; untroubled and uncomplicated by the superficial considerations of making the organism visually agreeable to those who view it. One could say that there are exceptions to this, especially in such cases as flowers designed to attract bees, butterflies, beetles, or flies. While the design of the flower is functional in its purpose, the attraction a bee feels toward the flower's aesthetic is the flower's function.

With manmade objects, such as a car, there is both a functional design (position and shape of the engine, transmission, tire width, roll cage, etc) and an aesthetic design (shape of taillights, hood, doors, curvature of the body). While the aesthetic parts of the car's design also serve functional needs such as aerodynamics, their main purpose is to hide the strictly functional parts of the design and to make the car's aesthetics agreeable to observers or interested buyers. A car's design has to agree with what we believe is aesthetically pleasing for a car. ${ }^{4}$

\footnotetext{
${ }^{3}$ Leo Marx, The Machine in the garden: technology and the pastoral ideal in America. Leo Marx (New York: Oxford University Press, 1964), 9.

4 Ralph Gilles: Automotive Design, prod. Michael Pantaleo, dir. Will Basanta and Clair Popkin, perf. Ralph Gilles, Abstract: The Art of Design, February 2017, accessed April 23, 2017, https://www.netflix.com/watch/80093806?trackId=14170289\&tctx=0\%2C4\%2C2929fb28-98ef-4bbe-864cc06d476ac66d-29126085.
} 
The objects I am particularly interested in are ones that exhibit no aesthetic intention. Utility poles, radio transmission towers, pumping stations, and electrical boxes all exist in a disagreeable environmental situation. Their size or accessibility-needs force them to inhabit our shared visual space, but the necessities of their design and cost force them to be strictly functional. The result is that they represent a utilitarian manmade design that cannot effectively be hidden from the public's gaze, or altered to agree with our aesthetic sensibilities. Their ubiquity also forces us to confront their existence to some degree, but rather than embracing them, we become numb to their presence in our surroundings. When I show images of the radio towers in Morgantown, West Virginia to residents, the reaction often is, "Oh, I had never noticed that was there." What a strange response to seeing a several hundred foot tall steel tower, a massive vertical line on a predominantly horizontal landscape!

While the professed interest of my work is infrastructure in a general sense, the specific focus of this thesis exhibition is the radio transmission tower. It is my belief that to cast a wide net and talk about infrastructure in general within one exhibition would blunt the effectiveness of the intent. Infrastructure is a large category of objects that not only includes radio towers and aforementioned object types, but bridges, dams, drains, pipelines, stoplights, as well as every manner of road components and signs. To make an exhibition about all these objects at once was an option, but I believe the inclusion of one object type and exclusion of another would be something arbitrary and indefensible. Focusing solely on radio transmission towers provided an opportunity to make multiple works about their forms, allowing a viewer to see a short typology of them. This was the rationale for an exhibition focused on only one type of infrastructure object. My choice of the radio transmission tower as the specific subject of the exhibition is grounded in their size and relationship to the landscape. There is no other infrastructure object so incapable of being hidden, so large and outstanding in the landscape, so closely a reflection of its landscape, and so directly related to our current times. While AM antennae go back to the 1920s, the advent and proliferation of the modern cell tower has only happened within the last few 
decades. ${ }^{5}$ No other infrastructure object better exemplifies the uncanny relationship between a utilitarian object's design and its surrounding natural landscape.

\section{THE TECHNOLOGICAL SUBLIME}

"In a physical world that is increasingly desacralized, the sublime represents a way to reinvest the landscape and the works of men with transcendent significance."

David E. Nye, American Technological Sublime

The Oxford English Dictionary defines 'sublime' as, "Producing an overwhelming sense of awe or other high emotion through being vast or grand". ${ }^{7}$ In David E. Nye's American Technological Sublime, he describes the sublime as "an essentially religious feeling, aroused by the confrontation with impressive objects." the presence of something", is conjured at the rim of the Grand Canyon, in front of a massive sequoia, or at the foot of a mountain, but it is a feeling not limited to the works of nature. Nye goes on to list other sources of this sublimity within the manmade world: "the New York Skyline, the Golden Gate Bridge, or the earth-shaking launch of a space shuttle". It is apparent from the attention that the American public has paid to technological achievements in the last two centuries that there is a Technological Sublime at work in American society. ${ }^{10}$ That's not to say that there is an immediate and continuous level of sublimity found in our large technological objects. "Over time, the same objects cannot

\footnotetext{
${ }^{5}$ Douglas B. Craig, "Radio, modern communication media and the technological sublime," Radio Journal:International Studies in Broadcast \& Audio Media 6, no. 2 (2008): 133, doi:10.1386/rajo.6.2-3.129/1.

6 David E. Nye, American Technological Sublime (Cambridge, Mass: MIT Press, 1994), xiii.

7 "Definition of sublime in English," Oxford Living Dictionaries, , accessed March 29, 2017, https://en.oxforddictionaries.com/definition/sublime.

8 Nye, American Technological Sublime, xiii.

${ }^{9}$ Ibid.

10 Ibid.
} 
always be counted upon to evoke the sublime response," ${ }^{11}$ Nye says. Certainly, the omnipresence of a specific form of infrastructure across the landscape can undercut its continued sublimity, and change its reception from sublime to mundane.

Sublime and mundane seem to belong on opposite sides of a spectrum, but when the mundane is observed carefully, and from up close, it can enter the realm of the sublime. "The aspects of things that are most important for us are hidden because of their simplicity and familiarity." Ludwig Wittgenstein writes, "(one is unable to notice something - because it is always before one's eyes.)" 12 The ubiquitous nature of the radio transmission tower, and our collective dismissal of its presence places it firmly within the realm of the mundane. This is, of course, when it is out on the horizon, far away from us. As a part of making my work, I depend upon photos of the tower taken from nearby, and this requires locating and trekking to the tower in person. Often towers do not have proper addresses that would allow a GPS to find them, so the process of getting to them involves driving in their general direction, guessing distances, tracking my own position in relation to the tower, and then, eventually trekking to its base. Such hikes create memories for me, memories of beautiful views, getting lost, being exhausted, or dealing with a prolific tick population. These hikes also remind me of my experiences as a child thrusting the net into the pond. At some point, people worked together with equipment to put this tower here, and the whole thing was designed and constructed with great care. Someone, somewhere knows everything about it, but it's new to $m e$. Standing in front of one of these radio transmission towers is indeed a sublime experience. The presence of such a large object is an experience that isn't possible to give the viewer through a print, drawing, video, or even virtual reality simulation. This experience belongs only to someone who seeks out such experiences.

I see my work as the results of this personal interaction with these objects in my surroundings, rather than an attempt to recreate the sublime experience of them. I seek to reference the act of observation in my prints through a direct and illustrative aesthetic with similarities to the taxonomic prints of $18^{\text {th }}$ and $19^{\text {th }}$ century naturalists. This aesthetic visually references the act of observation, as those prints were made in a time where learning

\footnotetext{
11 Ibid., xiv.

12 Ludwig Wittgenstein, Philosophical investigations: the English text of the third edition, trans. G. E. M. Anscombe (New York: Prentice Hall, 1968), 129.
} 
about nature had to be based primarily in direct observation, rather than primary or secondary sources. I have a particular nostalgia for the naturalist's or natural philosopher's relationship to their subject and their dedication to learning through direct observation.

John Herschel asserts, “To the natural philosopher there is no natural object unimportant or trifling... a soap bubble... an apple... a pebble... He walks in the midst of wonders." ${ }^{13}$ To furnish great focus and effort onto an otherwise overlooked part of my surroundings allows me to do just that, to walk in the midst of wonders.

\section{INFLUENCES}

Coming to understand my own motivations, and honing the aesthetics of my works' presentation were things discovered simultaneously with making. Understanding my work also came from research into artistic movements like Photorealism as well as individual artists investigating similar subject matter.

The content of my work, insofar as the redefining of the manmade as nature, owes a great deal to the work of Nicola Lopez. Her prints and drawings express a tension between the order and disorder of the built landscape, constantly built with a plan as well as growing organically according to its own rationale. ${ }^{14}$ (fig. 1) Lopez shines a light on manmade structures and detritus that are the result of seemingly autonomous processes. Her work acts as an aesthetic counterpoint to my own. As her imagery abstracts and warps the manmade to make it organic, I carefully render the manmade faithfully to celebrate its form and aesthetic.

Another contemporary printmaker investigating the mundane and manmade is Kevin Haas, whose work specifically focuses on the "sprawling commercial developments found just off highways, the construction cranes and glass condos transforming city skylines, and the clutter and detritus found throughout the urban landscape." ${ }^{15}$ Haas often takes mundane subjects like a gas pump console, or an electrical box and forces them to be central

\footnotetext{
13 Richard Holmes, The age of wonder: how the romantic generation discovered the beauty and terror of science (New York, NY: Pantheon Books/Vintage Books, 2010), xiii.

14 Nicola Lopez, "Statement," Nicola Lopez -Bio, , accessed January 12, 2017, http://nicolalopez.com/info_statement.htm.

15 Haas, Kevin. "About." Kevin Haas. Accessed January 13, 2017. http://www.kevinhaas.com/about.
} 
by placing them in the middle of the image and erasing their surroundings. (fig. 2) In this way, the ignored object becomes impossible to ignore, and the rather involved printmaking process (usually lithography) that gave birth to such an image demands attention from the viewer. The viewer has to ask the question, "Why spend so much time rendering this?" In this way, Haas's attention to detail and painstaking technique imbues the objects he is depicting with something that makes them worthy of the viewer's attention. If he can make the viewer see these illustrations of often-ignored objects in a gallery, then there is a real possibility that when the viewer leaves the gallery, they will begin to notice those objects around them in their everyday lives. I follow a similar approach in my own work. To keep the attention of a viewer for more than a glance, I take advantage of the intricate line work an etching affords me, pulling in the viewer to investigate the small details of a structure they would normally ignore.

In the fall of 2013, I had an incredible opportunity to research a number of artists' books at the University of Iowa Library's special collections. Among the amazing and impressive series of handmade books was a half-leather bound special edition book titled The Mayflies of the Driftless Region by Gaylord Schanilec. (fig. 3) The book contains 13 color wood engravings (fig. 4) of mayfly specimens caught in the ancient geographic feature of Southwestern Wisconsin known as the Driftless Region, where Schanilec lives and works. ${ }^{16}$ The mayfly specimens were collected near his home and after examination under microscope and engraving, they were sent to Clarke Garry, an entomologist at the University of Wisconsin-River Falls, who worked to identify them. ${ }^{17}$ Interestingly, despite his best efforts some could not be identified. Beside the illustrations of these specimens are notes as to what their physical characteristics are, and why they cannot be identified. ${ }^{18}$ In support of this artist's book of entomological specimens, Schanilec boldly asserts, "The scientist, and the artist, do basically the same thing: we observe the world around us, and record our

\footnotetext{
16 "Mayflies of the Driftless Region," The Freshwater Blog, May 20, 2011, , accessed April 6, 2017, https://freshwaterblog.net/2011/05/20/mayflies-of-the-driftless-region/.

17 Ibid.

18 Ibid.
} 
observations as best we can." 19 The effort and focus Schanilec furnishes upon these mayfly specimens was of great influence on how I approached my own taxonomic efforts.

With a somewhat similar visual approach to both Schanilec and Haas is Michael Landy's series of etchings titled "Nourishment". The prints depict twelve weeds, or 'street flowers' as Landy prefers, placed in the center of the print and offer a complete lack of any surroundings. ${ }^{20}$ The subject of Landy's "Nourishment" series is ostensibly plants in the same sense as the botanical illustrators of past centuries rendered plants, but Landy's prints significantly differ in approach. The academic and scientific prints of botanical taxonomists picture a plant in an idealized form without frayed edges, insect damage, or imperfection of any kind. Landy's prints show the weed as it is with all the imperfections intact. ${ }^{21}$ The works are all titled the common name of the plant, eschewing the Latin genus and species. Also, rather than making one piece that serves to visually define the form of one species of weed, Landy repeats species. Sheppard's Purse repeats four times in the series, and with great variation in the plant's form. (figures $5,6,7, \& 8$ )

This repeated featuring of the same plant species gave me license to repeat the radio transmission tower types in my own prints. I feature two 'guyed mast' type structures, two 'monopole' type structures, and a 'self-supporting tower'. Even when repeating structure types, their forms are significantly different. Like Landy's prints, I am not changing any of the towers to represent an idealized vision of each structure type. Each tower is faithfully reproduced just as it appeared in the landscape, idiosyncrasies intact. The asymmetrical placement of antennae, jumbles of wires, and auxiliary equipment are not omitted, and it is these things that are most unacceptable to the public's visual sensibilities. In the commercials for US Cellular's Nationwide Network, the company logo (fig. 9) appears as a sign perched atop a radio transmission tower. ${ }^{22}$ In the interest of visual appeal, the company edits out as much of the tower's idiosyncrasies as possible, leaving only a greatly simplified, symmetrical, and generalized form that would not affront viewers.

19 Gaylord Schanilec, "Notes on the Book," Gaylord Schanilec, fine printer and wood engraver, , accessed April 10, 2017, http://www.midnightpapersales.com/mayflies.html.

20 British Council, "NOURISHMENT," Visit Visual Arts, , accessed March 10, 2017, http:/visualarts.britishcouncil.org/collection/portfolios/nourishment.

21 Ibid.

22 "Uscellular_new.jpg," digital image, My Education Discount, accessed March 21, 2017, http://www.myeducationdiscount.com/images/uscellular_new.jpg. 
A similar attempt to present a viewer with a realistic, non-generalized rendering of nature comes from Albrecht Durer (b. 1471), who in 1503 drew The Great Piece of Turf(fig. 10) in watercolor and gouache. ${ }^{23}$ The mundane nature of a tuft of wild plants is unquestionable, and the detail with which the plants are drawn is evident in their easy identification even today. "A botanical eye can recognize several grasses, flowers and weeds cock's-foot, creeping bent, smooth meadow grass, daisy, dandelion, germander speedwell, greater plantain, hound's-tongue and yarrow." ${ }^{24}$ The philosophy of why he undertook making such a mundane but wondrous piece of realism is embodied in Durer's suggestion, "Therefore observe it diligently, go by it and do not depart from nature arbitrarily, imagining to find the better by thyself, for thou wouldst be misled. For, verily, 'art' [i.e. Kunst, or theoretical knowledge, as opposed to Brauch] is embedded in nature; he who can extract it has it." ${ }^{25}$ In this way, Durer advocates a strict adherence to rendering nature as it is, a counterpoint to the botanical illustrations of botanists like Johann Jacob Dillenius (b. 1684) or Otto Brunfels (b.1488) who instead depicted an idealized and posed version of their specimens. Their goal was to capture and transmit to those who might look at their prints the specific characteristics that make a species of plant identifiable. ${ }^{26}$

Within my own work, I choose to walk a line between these two modes of representation. My prints are hand-rendered and printed using a zinc etching process similar to that used by the old botanical illustrators, but I don't generalize the visual characteristics of my subject. Instead, as Durer insisted, I faithfully render the radio transmission towers. The results are images that closely resemble reality while not perfectly, hyper-realistically depicting it. In this way, I create taxonomic prints about radio transmission tower forms while retaining the aesthetics of each tower. To simplify or generalize a tower's appearance would change its aesthetics.

23 "The Great Piece of Turf," National Gallery of Art - Albrecht Dürer, The Great Piece of Turf, 1503, , accessed April 21, 2017, https://www.nga.gov/exhibitions/2013/durer/fullscreen.shtm.

24 Tom Lubbock, "Dürer, Albrecht: The Large Turf (1503)," The Independent, January 17, 2008, , accessed March 18, 2017, https://www.independent.co.uk/arts-entertainment/art/great-works/d-rer-albrecht-the-large-turf1503-770976.html.

25 Pamela H. Smith, “Artists as scientists: nature and realism in early modern Europe”, Endeavor. 24 (1) 2000

26 Kärin Nickelsen, "Draughtsmen, botanists and nature: constructing eighteenth-century botanical illustrations," Studies in History and Philosophy of Science Part C: Studies in History and Philosophy of Biological and Biomedical Sciences 37, no. 1 (2006): 5, doi:10.1016/j.shpsc.2005.12.001. 
Recording and presenting the myriad forms of manmade structures is a pursuit that owes much to Bernd and Hilla Becher. These artists are considered the definitive photographers of industrial archetypes like the coal tipple, water tower, blast furnace, and winding tower among many others. In the 1960's and 70's, their typologies of utilitarian industrial architecture served to record and celebrate the repeating forms of an architecture that transcends culture or style, instead taking design cues almost exclusively from necessity, economy, and physics. (fig. 11) In attempts to comment about their work, critics and writers often attempt to place the Bechers' typologies within some kind of socio-political or historical context. The critics draw upon surmised feelings of coldness or bleakness and at times call attention to the plight of the workers who had toiled at such structures. ${ }^{27}$

There is an inclination for people to place artworks within a popular discourse, but these angles from which to look at a series of works end up being about content inherent in the structures, but not inherent in the artwork about such structures. Some may look upon the radio transmission towers, or any other object in the landscape, from an environmental perspective, which necessitates a 'good or bad' appraisal of the structure's overall environmental impact. I sidestep participation in this discourse. While I argue that in the more inclusive sense radio transmission towers are a part of nature, I make no appraisal of their environmental impact, or even of their practical use in our communications with each other. These are legitimate discourses, but to participate in them would detract from the observational focus of the work.

27 Bryant, David. "Typologies". Library Journal. 129, 11 (2004): 67. 


\section{EXHIBITION}

"[He] maintained that his contemporaries would consider a botanical work without illustrations as ridiculous as a geographical work without maps.”28

Kärin Nickelsen, Draughtsmen, Botanists and Nature: The Construction of Eighteenth-Century Botanical Illustrations

The path by which a viewer experiences a space such as the Laura Mesaros Gallery, a room with a single entrance and exit, is circular. Whatever is experienced first is also experienced last. With this in mind, the atrium of the gallery can be seen as both a Preface/Introduction as well as an Appendix.

The three walls of the atrium, all of which face the viewer as they walk into the gallery, contain alternately essential components of the exhibition like the artist statement, price list, and exhibition title, as well as marginalia and ephemera like layout diagrams, lists, notes, and tools. (fig. 13)

The title of the exhibition, displayed on the right-most wall of the atrium in cut vinyl lettering, reads An Abridged Study of the Radio Transmission Tower Landscape Surrounding West Virginia University's Evansdale Campus. (fig. 14) (Referred to as An Abridged Study, hereafter.) The title is intentionally long, referencing the often long and unwieldy titles of $17^{\text {th }}$ and $18^{\text {th }}$ Century treatises. The way the text is displayed mimics the typography of those treatises as well, with alternating lines of large and small text.

In the center wall of the atrium are three wooden display shelves organized one on top of the other. This piece, Notes, Maps, Surveys, Tools, \& Schemata, is a collection of ephemera and reference material used during the planning and making of the exhibition. (fig. 12) The center shelf contains a folding portfolio of tower positions, names, and a chart for the conversion of latitude and longitude coordinates into degrees from North. Much of the work displayed on the shelves is impenetrable, indecipherable, or without context, so rather than acting as an explanatory device directing the viewer, the papers serve as leftovers of the

\footnotetext{
28 Kärin Nickelsen, Draughtsmen, botanists and nature: the construction of eighteenth-century botanical illustrations (Dordrecht: Springer, 2006), 1.
} 
exhibition as a performative act. The positions of towers in the Morgantown area are plotted out with dots on red grid paper, and at the center of the grid is the Creative Art Center where the exhibition itself is being held. Other illustrations display diagrams of wooden structures used to hold drawings in the exhibition, unsuccessful predecessors to those wooden structures, or schematics for lecterns and other objects never made. Through the display of these materials, the focus of the exhibition is shifted slightly. What was otherwise an exhibition very specifically and exclusively about Morgantown's radio transmission towers and their place in the environment becomes an exhibition also about the act of making such an exhibition.

\section{PRINTS}

The gallery's main space is occupied by five prints and a large panoramic drawing displayed in an open circle. The print nearest to the ramp is 1233759 , a zinc etching on Stonehenge natural-colored paper torn down to make four deckled edges one and a half inches away from the plate impression. (fig. 17) The tower imagery, as with all the other prints, does not include the base of the radio transmission tower. When seen, towers like this usually appear through the treetops and we are unable to see their bases. The prints recreate this appearance of the tower against a blue sky. The black line work of the print is etched into the zinc printing matrix with nitric acid and an aquatint process is used to add shading. On some prints, the aquatint is used for all the shading and on others, only the gray tones of the sky. After printing, the border areas of the print are protected with a simple stencil and a mixture of blue watercolor and white acrylic paint is airbrushed onto the work. This layer of airbrushed color creates a delicate blue tone that overlays the aquatint to form

the sky behind the tower. When dry, the print is then drawn on with colored pencil, and in some cases, a white charcoal pencil, to further develop the imagery.

As a part of the preparation of the print, the plate was polished to a high degree before any etching so that those areas of the plate left blank (nearly three quarters of an inch on each side) would hold very little tone. In this way, the bevels of the plate are distanced 
from the actual image area and the drawn box that contains the radio transmission tower imagery can be cleanly wiped during the printing process. Aesthetically, the lightly toned imprint of the plate against the paper serves as another level of separation between the imagery of the radio transmission tower and the surrounding visual space. The printing and framing of the image creates at least five implied boundaries separating the tower imagery from the gallery wall: the etched rectangle, the plate impression, the paper's deckled edge, the inner edge of the wooden frame, and the outer edge of the wooden frame. All these boundaries serve to isolate the tower imagery and to make it precious. This precious quality is enhanced by floating the print roughly half an inch in front of the gray back of the frame. The wooden parts of the frame used to hold the print in this position are neither as wide nor as tall as the print itself. In this way, they remain hidden behind the paper.

No glass or Plexiglas separates the print from the viewer. The viewer is then free to very closely examine the print without any glare or reflection. It was important to me to have the prints inhabit the same space as the viewer in the exhibition. Having them floated, and not behind glass, made them objects, even if they were flat objects. This extra dimensionality separates them from the flat, backlit, immaterial imagery of our computer screens. The prints exist as real, material things.

Directly below the print is a dark gray label with the tower's structure type, major components, and Federal Communication Commission (FCC) designation. For 1233759, the label reads "Guyed Mast" for the structure type, and the major components are listed as “(Transmission Bays \& Dipole Antennae) (Microwave Antenna)”. Below this is “1233759”, the tower's FCC designation. By giving this sparse information, the tower's form is described through the listing of its major components and structure type, and the tower as an individual object is labeled with its official FCC designation while never attempting to explain the tower's function. In this way, the tower is labeled and described, but the work remains strictly about its form.

The label itself is made of a zinc plate that was coated with asphaltum applied using a screen-printing technique. The asphaltum served to protect areas of the plate that were not part of the text, which was then to be etched. The plate was exposed to nitric acid for nearly an hour. When washed off and the asphaltum removed, the text area was etched so that the letterforms were below the surface of the plate. Then graphite etching ink was 
applied to the surface of the plate with a brayer and the plate was heated to $450^{\circ} \mathrm{F}$ to dry the ink. The texture of the dry ink results in a label that is clean and legible while not looking store-bought. The metal and permanence of this type of label references those used for museum exhibits. If I am performing the role of being a Naturalist of the Artificial, then An Abridged Study should function not only as an art exhibition, but as an exhibition of visual specimens of radio transmission towers.

\section{DRAWING}

Displayed in an open circle, and straddling three walls of the gallery is a drawing measuring 16 inches tall by 579 inches wide. Made of the same natural-colored Stonehenge paper as the prints, the panoramic drawing represents $340^{\circ}$ of the horizon as seen from the Evansdale Campus of West Virginia University. (fig. 21) Within this portion of the horizon, those radio transmission towers visible from Evansdale campus are rendered along with their surrounding landscape. While the purpose of the prints was to divorce the towers from their surroundings and present them alone as forms worthy of aesthetic appreciation, the purpose of this drawing is to re-inject them into the landscape, and have the viewer re-experience their presence within it.

Making a panoramic drawing such as this took calculated planning to determine scale and placement. After taking measurements, it was apparent that the drawing would need to have a radius of 120 inches to span the width of the Laura Mesaros Gallery. This dictated that if the drawing were to be a full circle, it would be 754 inches long. With this in mind, the drawing was made to be 579 inches long so that sufficient space would be allowed for viewers entering and exiting. The process of making such a large drawing and calculating the placement of towers within it was approximate to cartographic methods. This mapping of my surroundings was part of my impetus for making the piece and something I also wanted the finished work to reference.

When I first arrived in Morgantown, West Virginia, determining my location and direction was something I had problems doing. I had moved from Illinois where the flat land 
allowed the majority of roads to be in a grid system, and suddenly living somewhere with twisting and turning roads everywhere undermined my sense of direction. It was the radio transmission towers of Morgantown that first helped me get my bearings on where I was and what direction I was going. Even at night, their beacon lights would occasionally help me orient myself. There was importance in their locations, and those who had built these towers had certainly picked their locations for practical reasons. The placement of the towers is directly related to the topography of the landscape, the population of the area, and the placement of other radio transmission towers. ${ }^{29}$ While the forms of each tower are dictated by the necessities of their utilitarian functions, their placement also adheres to a similarly functional aesthetic. In rendering a kind of map of their locations in the landscape, this placement can be shown clearly within the gallery space as a focus of the exhibition.

Geographia, an atlas created by the Greco-Roman geographer Ptolemy around 150 C.E., endeavored to depict the known world. ${ }^{30}$ When his works were rediscovered by the Western World during the Renaissance, there was a paradigm shift in cartography. European mapmaking, up until then, depicted the size of locations by their importance. ${ }^{31}$ That which was important was shown to be very large, and that which was unimportant was left small, which created maps with massive inaccuracies and distortion. Ptolemy's map was inaccurate as well, but it introduced mathematics and coordinates into cartography and established physical accuracy as a goal for mapmaking. ${ }^{32}$ There is a parallel between this and the way I am choosing to illustrate this drawing. My own aesthetic sensibilities and compositional preferences would result in a drawing that is a reflection of my own proclivities rather than a reflection of reality, so the drawing depicts the towers and landscape on their own terms.

For practical reasons, the drawing is split into three equal lengths of 193 inches that snap together magnetically. These sections hang from a curved wooden structure to which they are also held by magnets. The curved structure is made of an untreated poplar, the same wood used to construct the shelves for Notes, Maps, Surveys, Tools, \& Schemata as well as the

\footnotetext{
29 "Understanding Wireless Telephone Coverage Areas," Federal Communications Commission, October 26, 2016, , accessed April 12, 2017, https://www.fcc.gov/consumers/guides/understanding-wireless-telephonecoverage-areas.

30 "Ptolemy's World Map," The British Library - The British Library, , accessed March 12, 2017, http://www.bl.uk/learning/timeline/item126360.html.

31 Ibid.

32 Ibid.
} 
frames for the prints, adding cohesiveness to the exhibition. This wooden structure is made up of 48-inch segments of bent poplar that are overlapped and bolted together during installation. It is this structure that gets attached to the walls and hung from the ceiling. The entire structure is hidden by the drawing, making it appear to hover at eye level. The Stonehenge paper used to make this work is mildly transparent, so a black Tyvek backing was adhered to the back of the drawing to make it opaque, improve rigidity, and to act as protection from tearing or stains.

To gather the photographs used as reference material for the drawing, I went to two buildings on campus where large segments of the horizon were visible. The photos were merged together digitally, and then divided into sections for printing. The outlines of these sections are marked and labeled on the finished drawing as a remnant of the making process. The time and location in which the photos were taken is also written in the piece. While each of the towers visible from campus is drawn in the piece, markers are also drawn in for towers with known positions that are otherwise obscured. The markers drawn in for these towers are sized according to the tower's distance from Evansdale Campus. (fig. 22)

The imagery of the radio transmission towers and their surrounding landscape is rendered in colored pencil with an airbrushed sky similar in appearance to the sky present in the prints. The landscape fades away with distance from the towers. The goal of this is to show the landscape while still making the drawing primarily about the towers and their placement in it. If the whole landscape were rendered, this specific focus would be undermined. In addition to this, around the drawings of the towers are stamped labels listing their FCC designations and below some of them are informal, handwritten notes of curiosities concerning the towers. 


\section{CONCLUSION}

An Abridged Study was an attempt to present an exhibition that addressed the mundane presence of the radio transmission tower, and of utilitarian forms in general, as something worthy of attention and appreciation. In utilizing the fine art practices of drawing and intaglio printmaking, the towers are isolated from their surroundings, presented as visual specimens, and then reintroduced into the landscape. The local specificity of this landscape grounds the work in personal experience, and makes a statement about the importance of direct observation. Secondary to these statements, the works serve me personally as a way of reinvesting my everyday surroundings with a sense of wonder. 
ILLUSTRATIONS

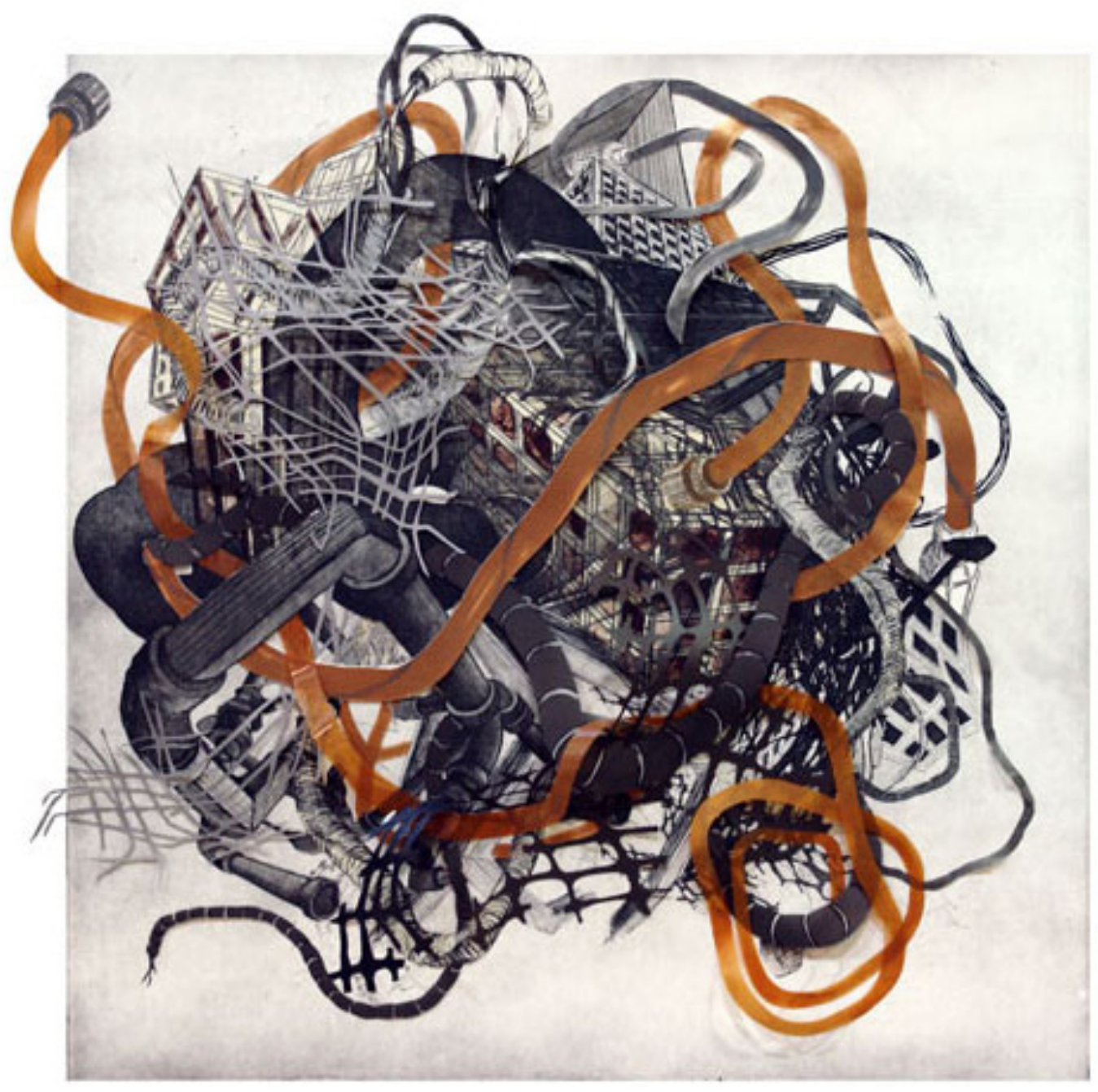

Figure 1. Nicola Lopez

Urban Transformation 4

Etching, lithography, \& woodcut on Mylar $30 " \times 30 "$

2009 


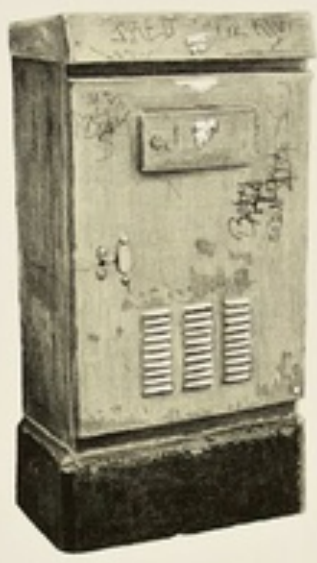

Figure 2. Kevin Haas

Inventory: Box

Lithograph

2010-2014 


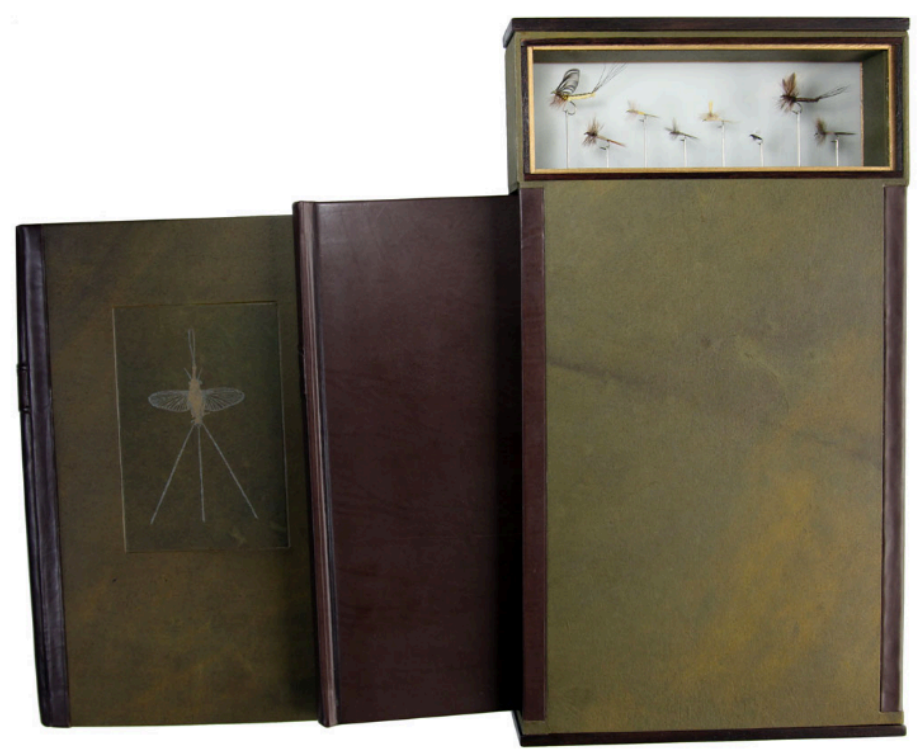

Figure 3. Gaylord Schanilec, Clarke Garry, Jill Jevne, Mary Hark, \& David Lucca Mayflies of the Driftless Region

$7.5 " \times 10.5 "$ (88 pages)

Wood Engraving, leather, wood, \& handmade paper 2005

Figure 4. Gaylord Schanilec PALE MORNING DUN Ephemerella inermis $4 " x 3.5$ "

Wood Engraving 2005 
Figure 5. Michael Landy

Sheppard's Purse 1

Etching

2002

Figure 7. Michael Landy

Sheppard's Purse 4

Etching

2002

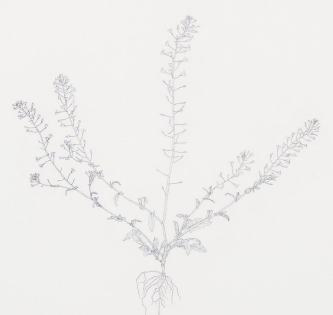

Figure 6. Michael Landy

Sheppard's Purse 2

Etching

2002
Figure 8. Michael Landy

Sheppard's Purse 5

Etching

2002 


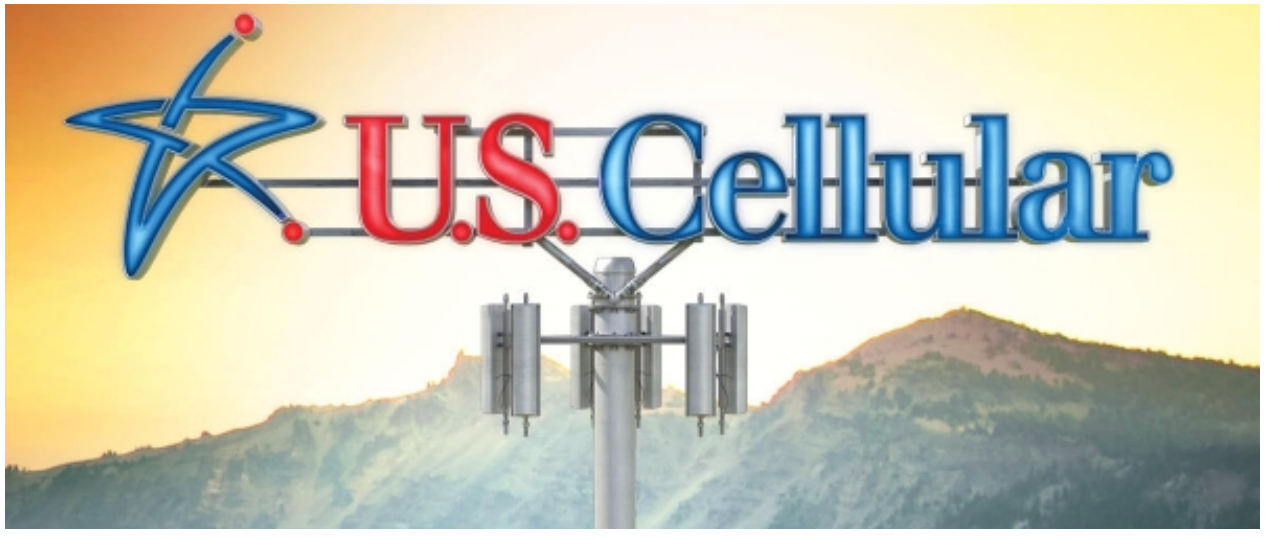

Figure 9. US Cellular

Logo from advertisement 2016

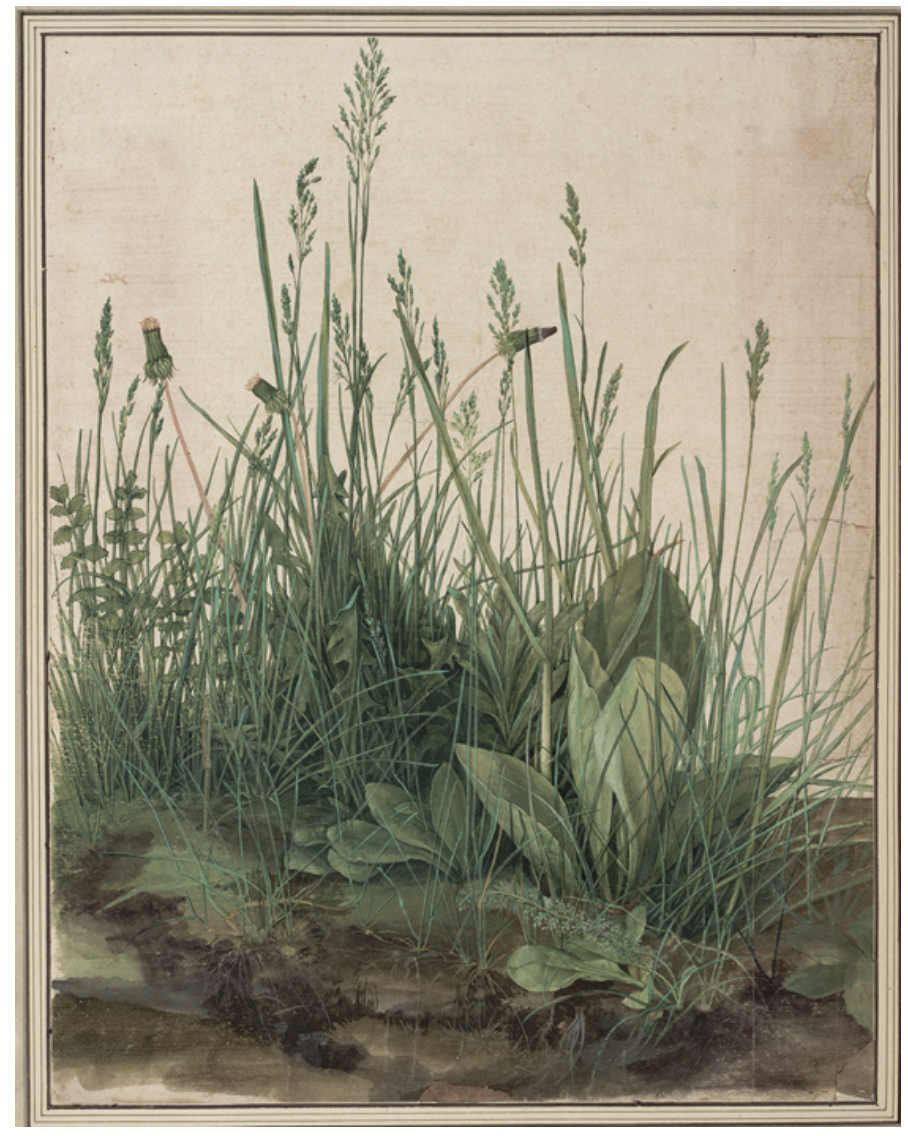

Figure 10. Albrecht Dürer The Great Piece of Turf Watercolor \& Gouache 1503 

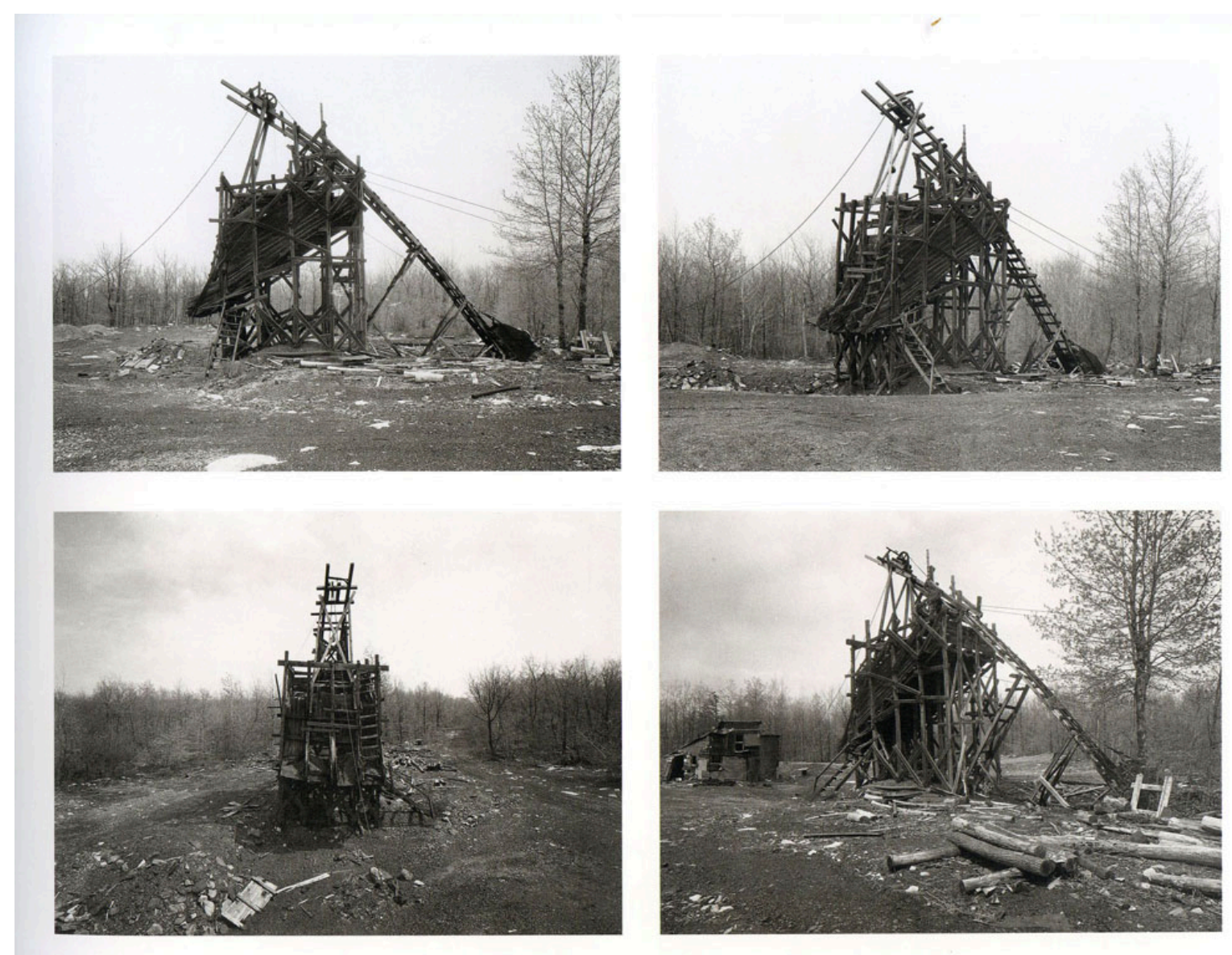

Figure 11. Bernd \& Hilla Becher Minnich Coal Co., Goodspring Mountains, Schuylkill County 1975

Published in Pennsylvania Coal Tipples

1975 


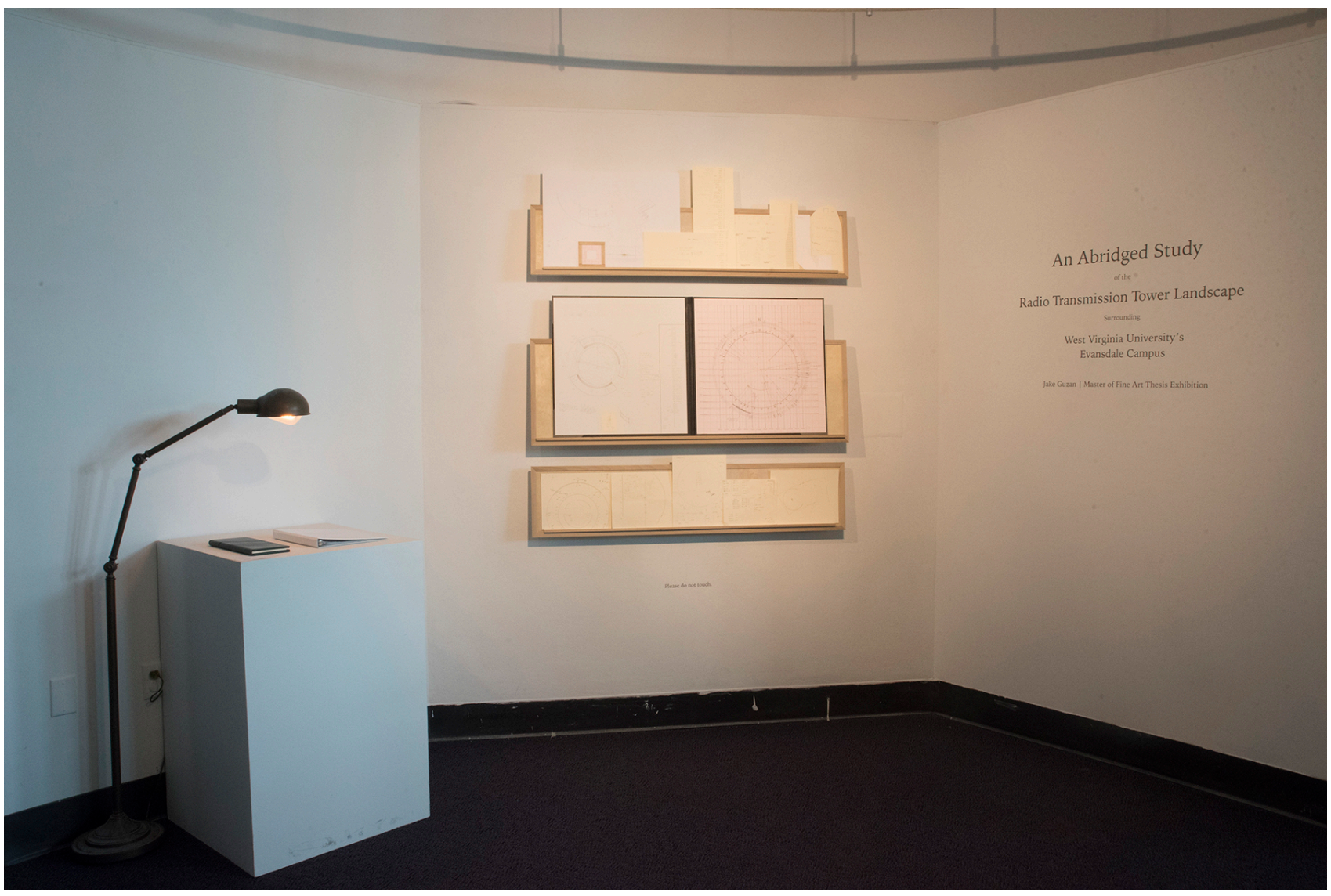

Figure 12. An Abridged Study

Atrium view

Laura Mesaros Gallery

2017 


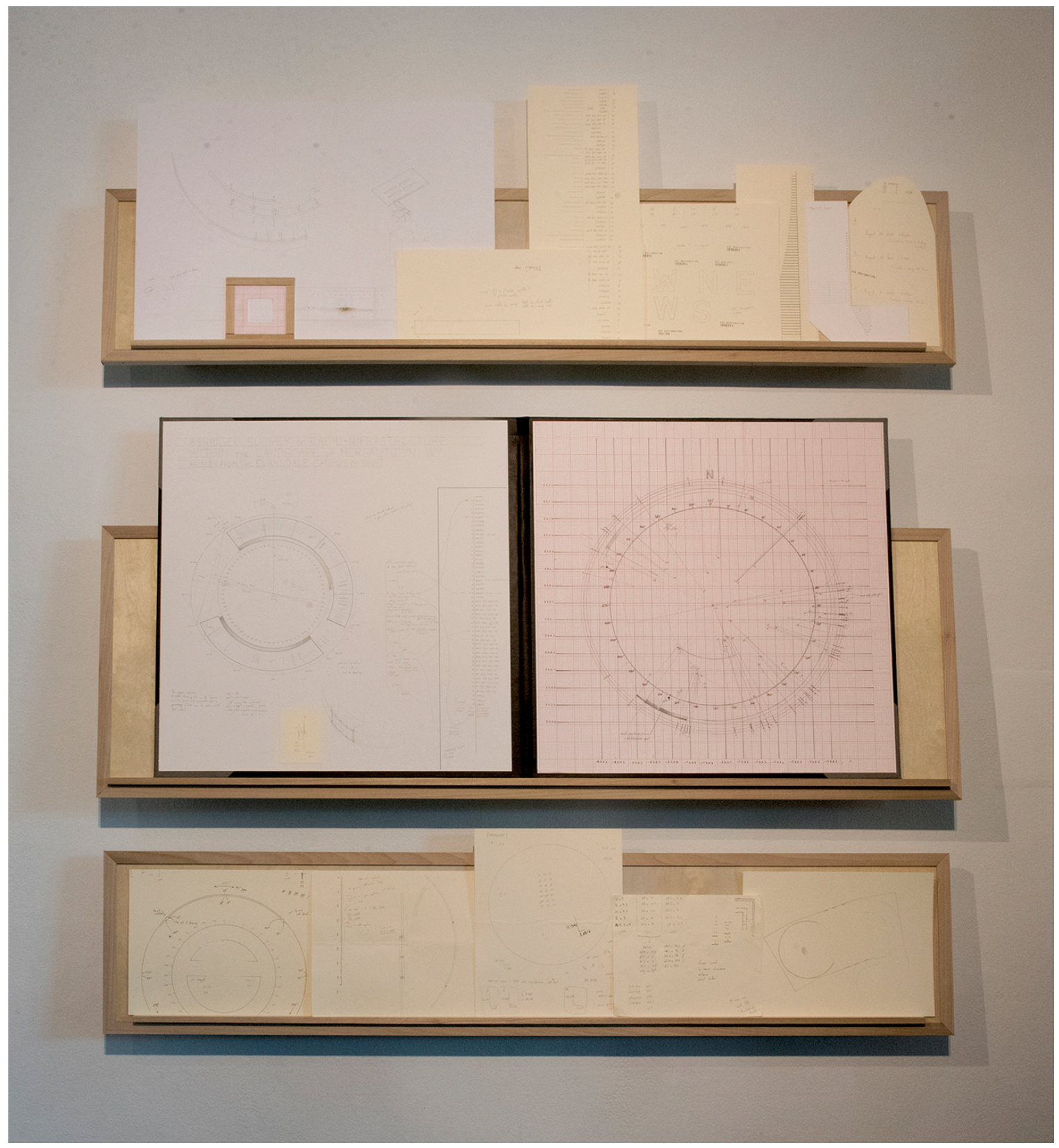

Figure 13. Notes, Maps, Surveys, Tools, \& Schemata

Cover-weight paper, Strathmore illustration board, grid-paper, ink, graphite, \& colored pencil 


\section{An Abridged Study}

of the

\section{Radio Transmission Tower Landscape}

Surrounding

West Virginia University's

Evansdale Campus

Jake Guzan | Master of Fine Art Thesis Exhibition

Figure 14. An Abridged Study

Exhibition title

Vinyl on wall 


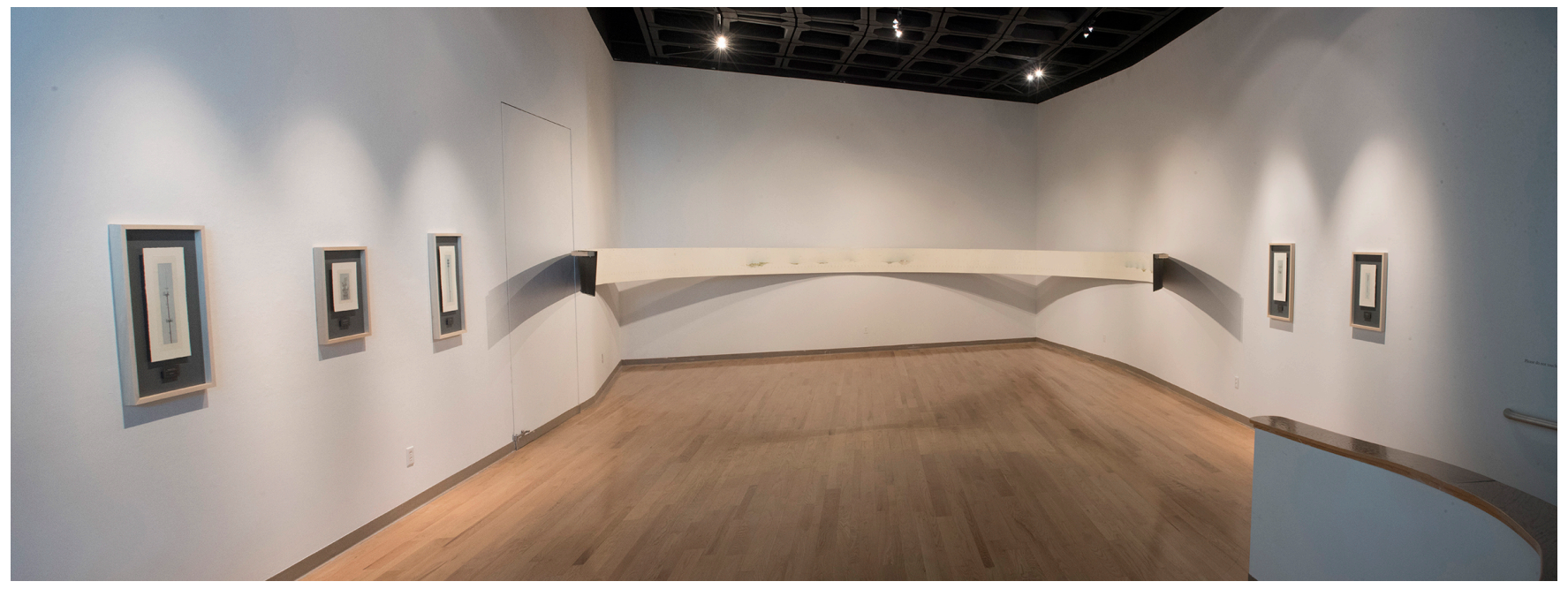

Figure 15. An Abridged Study

Exhibition view

Laura Mesaros Gallery

2017 


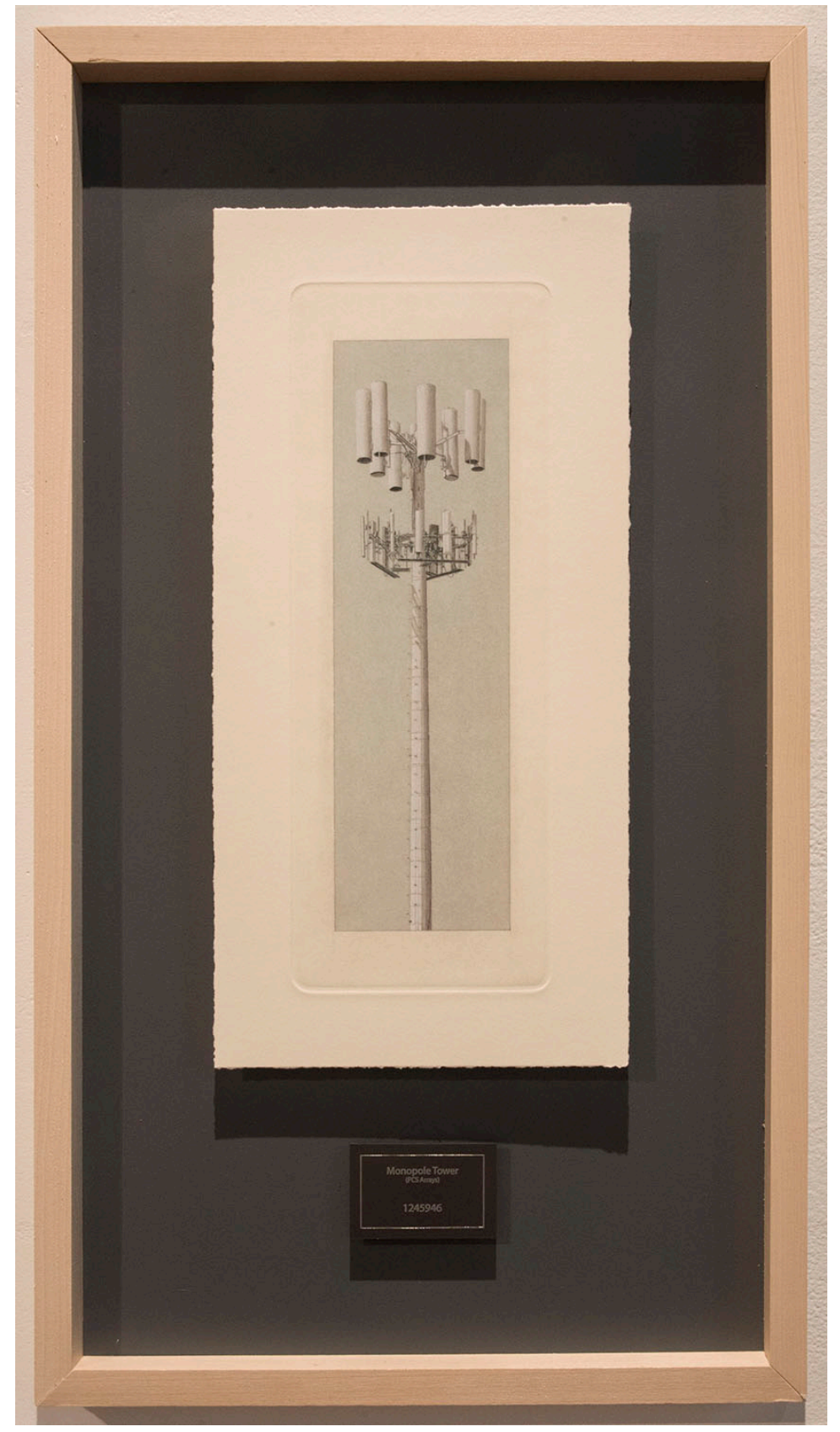

Figure 16. 1245946

Stonehenge natural-colored rag paper, zinc etching with aquatint, ink (black, graphite, \& tint base), acrylic, watercolor, \& colored pencil frame: 28 " x 15.5 " paper: $17.5 "$ x 8.5 " 2016 


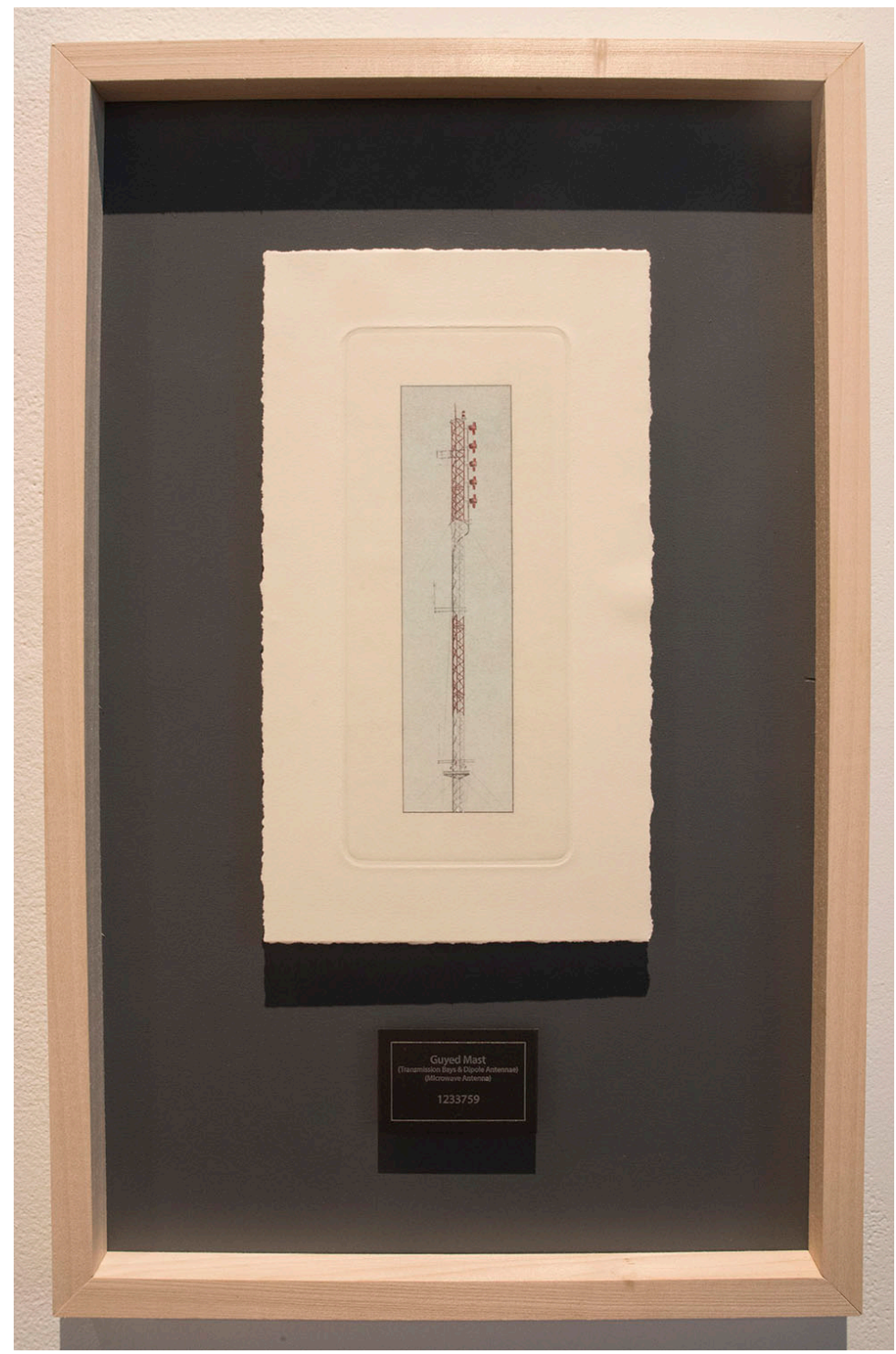

Figure 17. 1233759

Stonehenge natural-colored rag paper, zinc etching with aquatint, ink (black, graphite, \& tint base), acrylic, watercolor, \& colored pencil frame: $23.5 "$ x $15 "$ paper: $12.5 "$ x $7 "$ 2016 


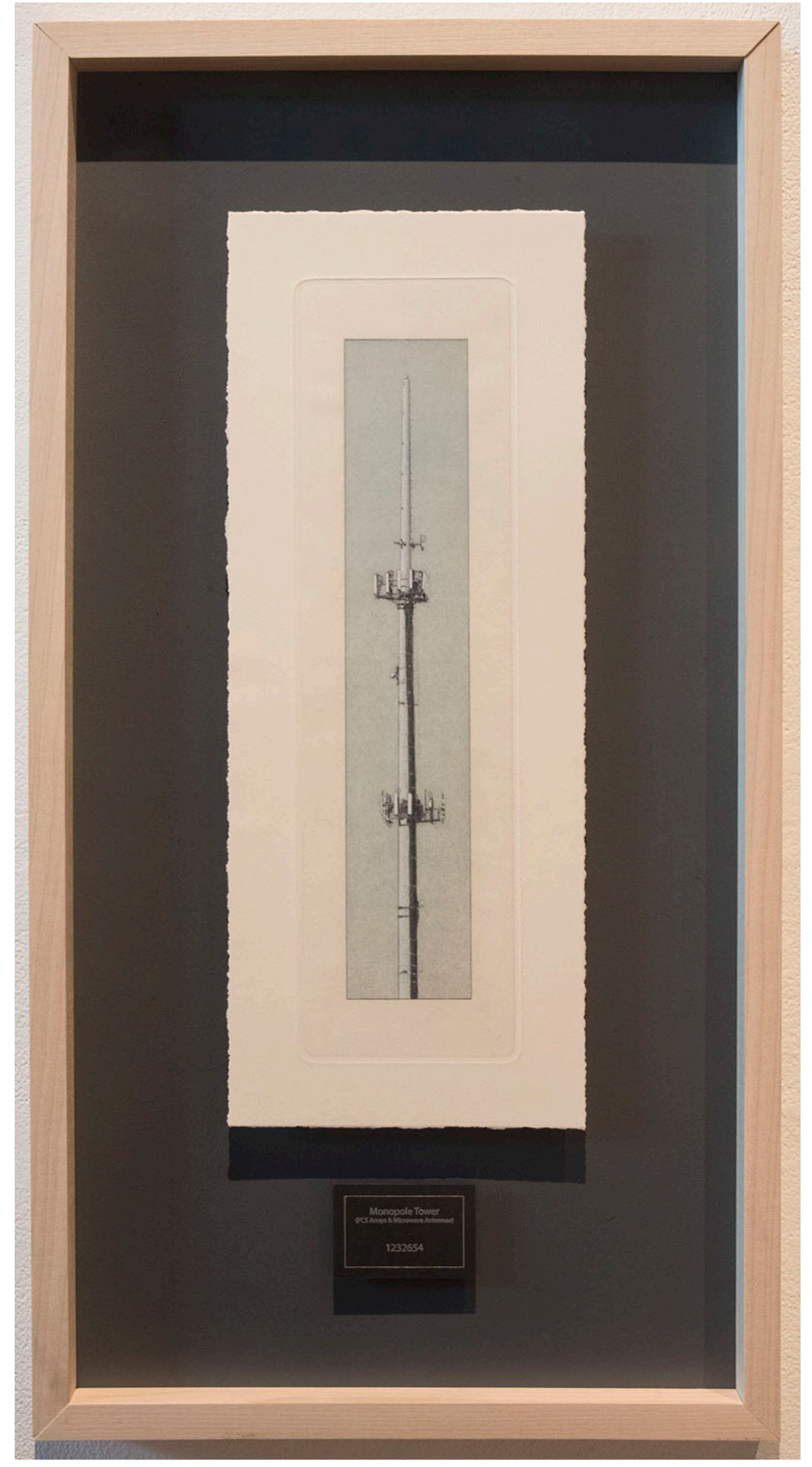

Figure 18. 1232654

Stonehenge natural-colored rag paper, zinc etching with aquatint, ink (black, graphite, $\&$ tint base), acrylic, watercolor, \& colored pencil frame: 29.5 " x 15.5 " paper: 19 " x 7.5 " 2016 


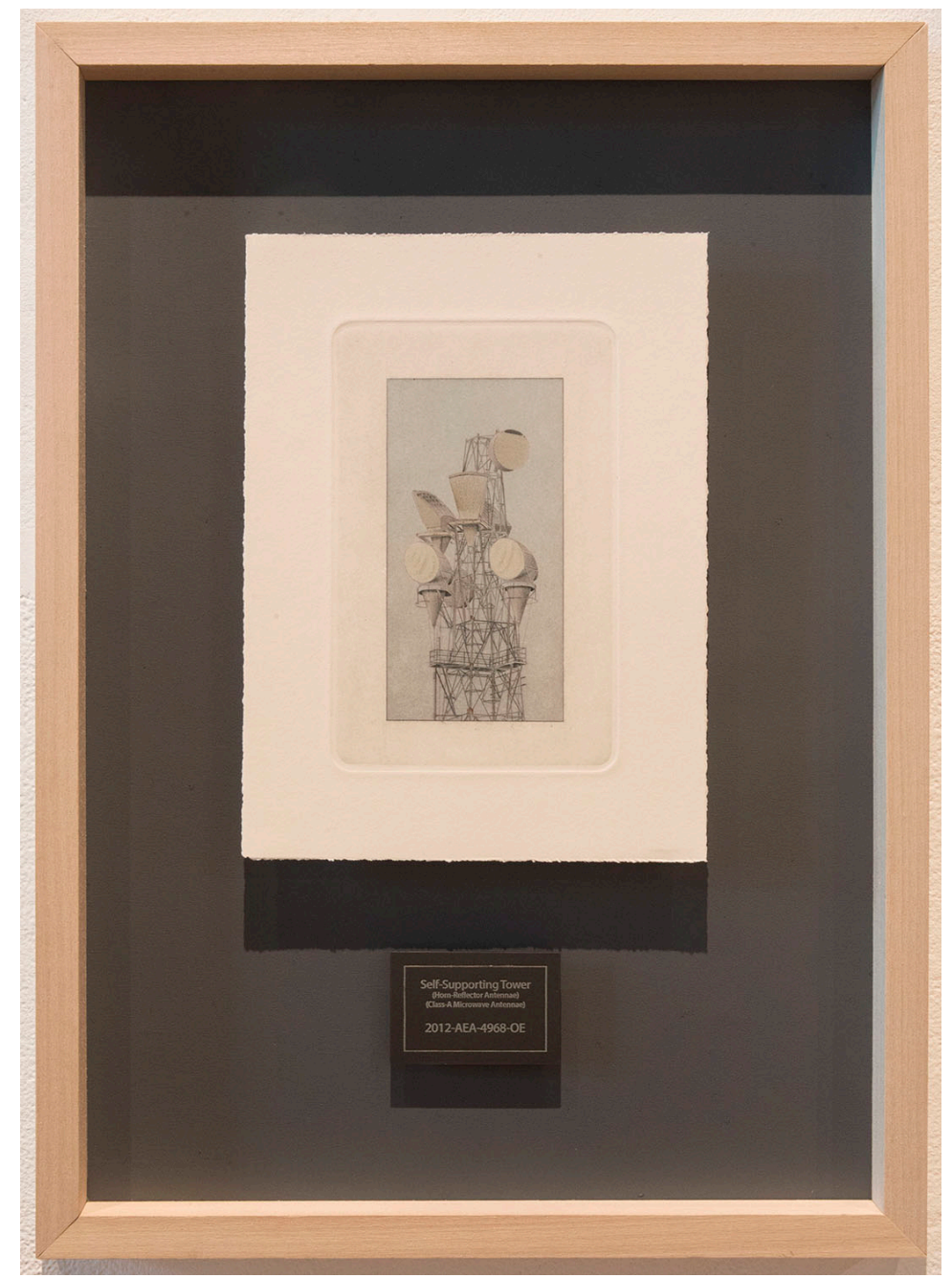

Figure 19. 2012-AEA-4968-OE

Stonehenge natural-colored rag paper, zinc etching with aquatint, ink (black, graphite, \& tint base), acrylic, watercolor, \& colored pencil frame: 21.5 " x 15.5 " paper: 11 " x 8 " 2016 


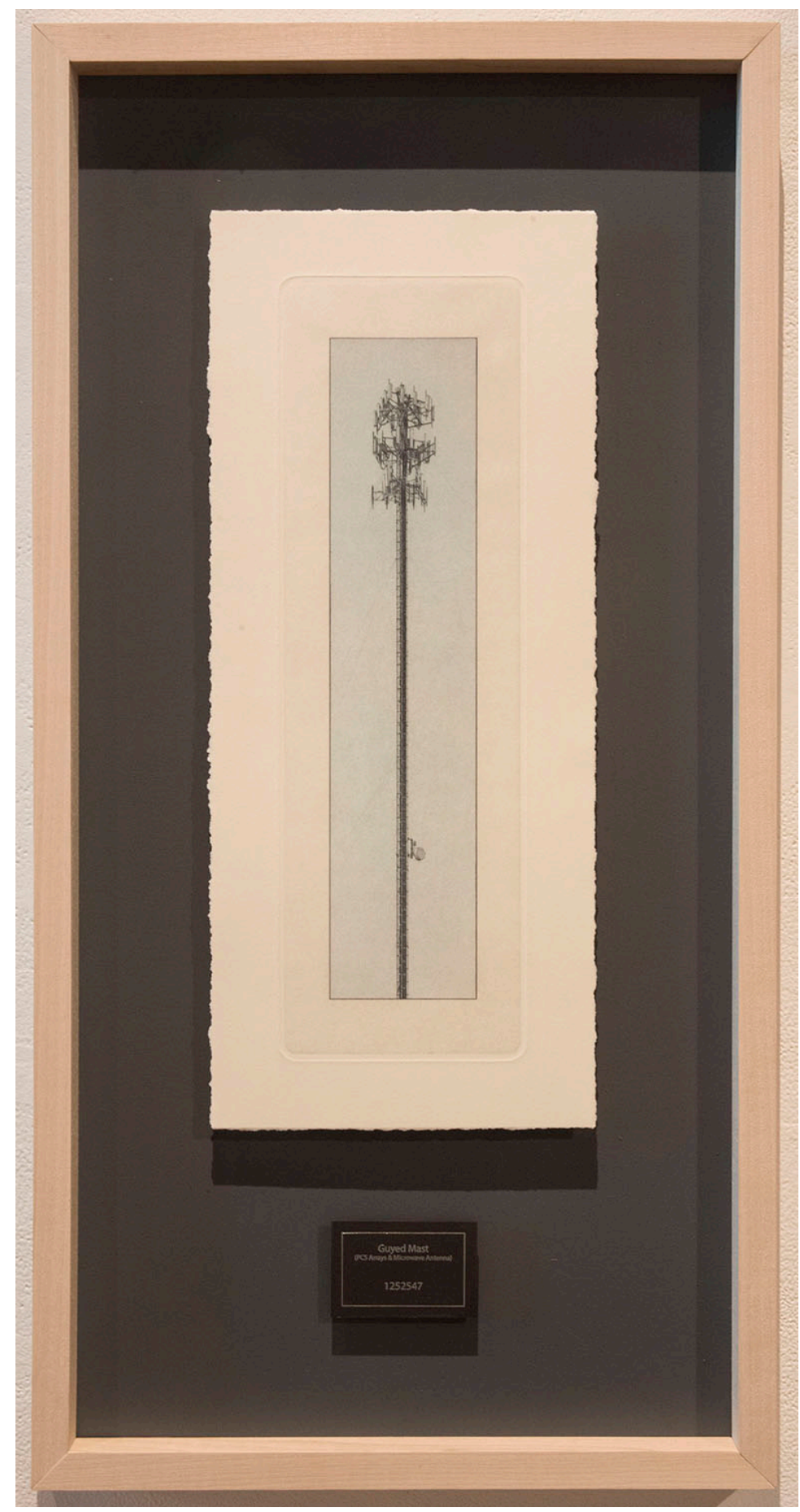

Figure 20. 1252547

Stonehenge natural-colored rag paper, zinc etching with aquatint, ink (black, graphite, $\&$ tint base), acrylic, watercolor, \& colored pencil

frame: 29.5 " x 15 " paper: 18.5 " x 8 " 2016 


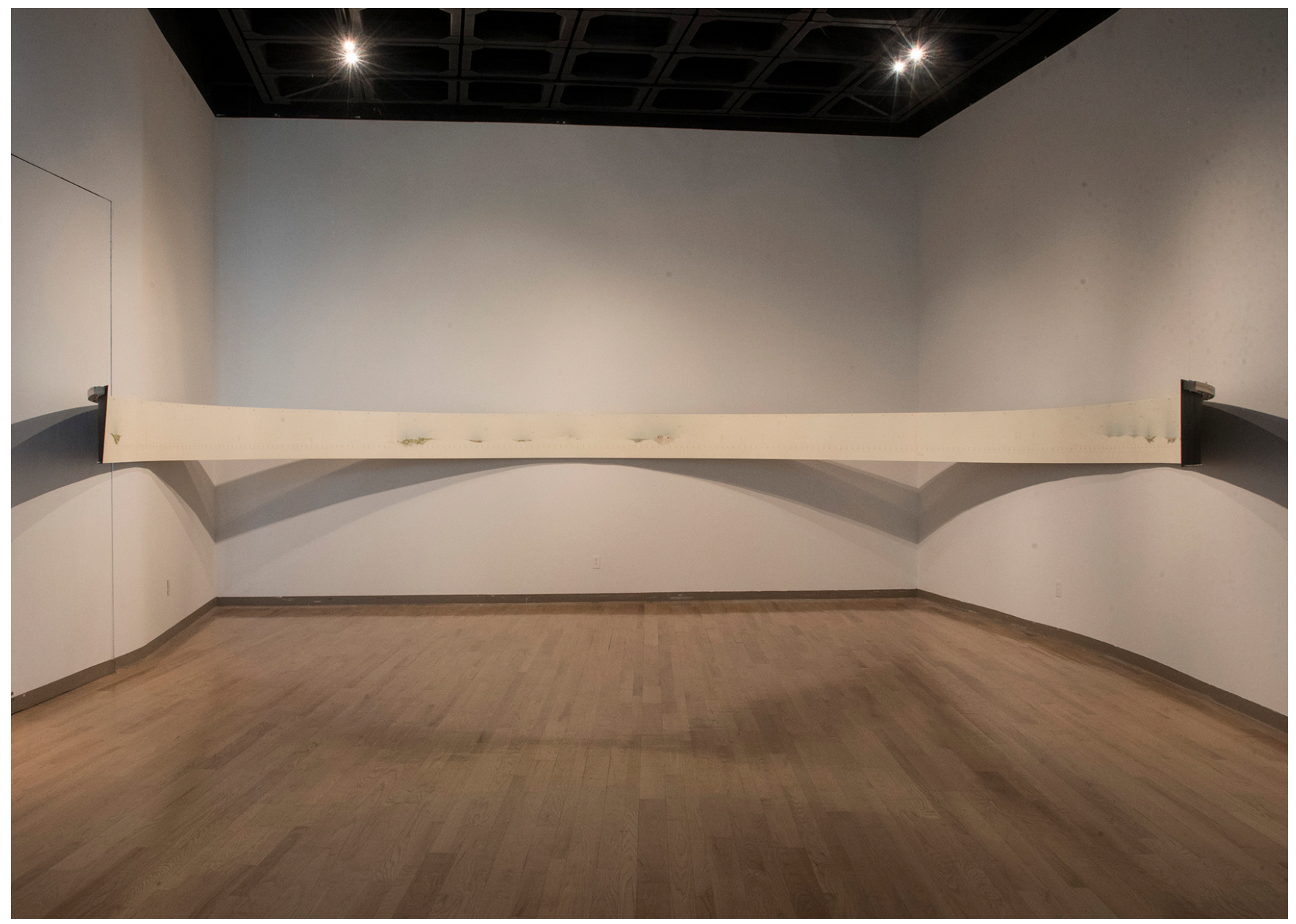

Figure $21.290^{\circ}-22^{\circ}, 23^{\circ}-114^{\circ}, \& 115^{\circ}-207^{\circ}$

Stonehenge natural-colored rag paper, Rives BFK paper, poplar, neodymium magnets, ink, graphite, acrylic, watercolor, \& colored pencil

$16 ” \times 579 ”$

2017 


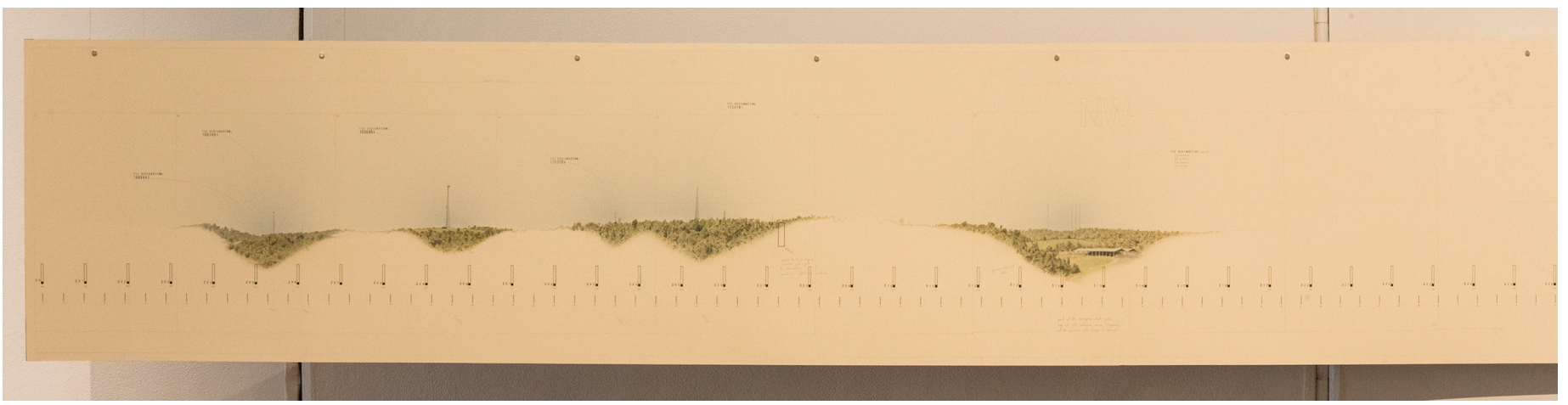

[far left]
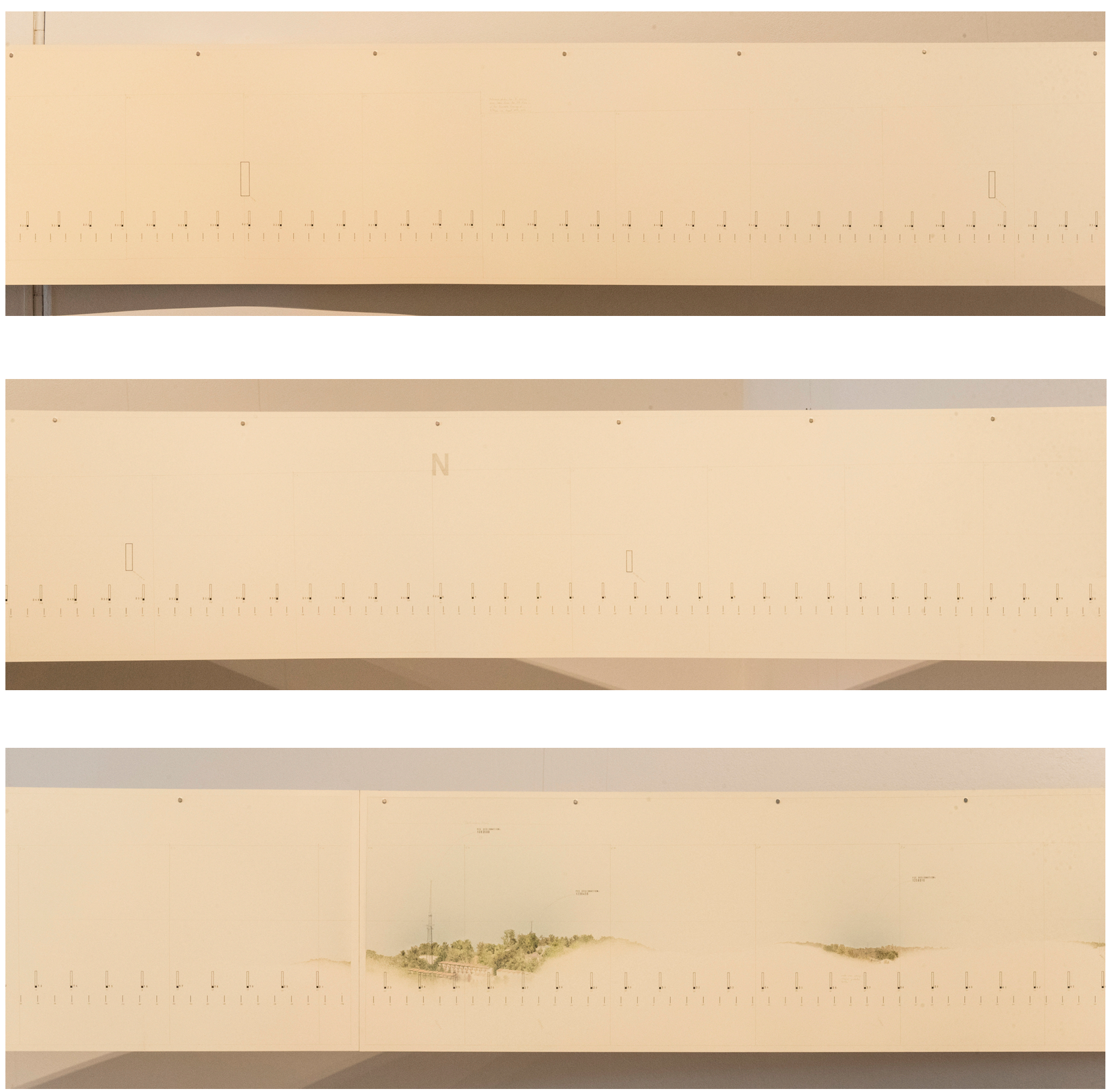

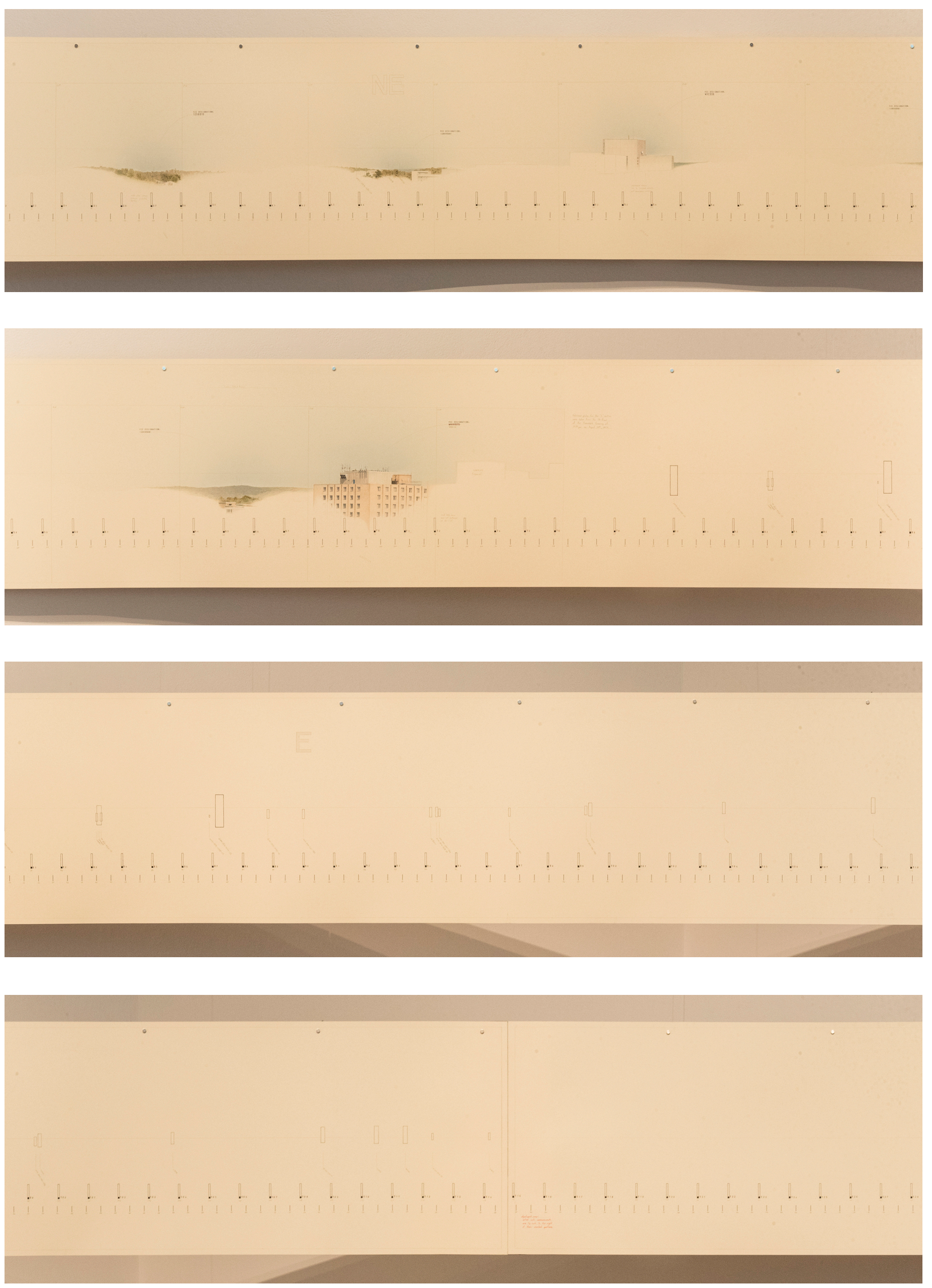

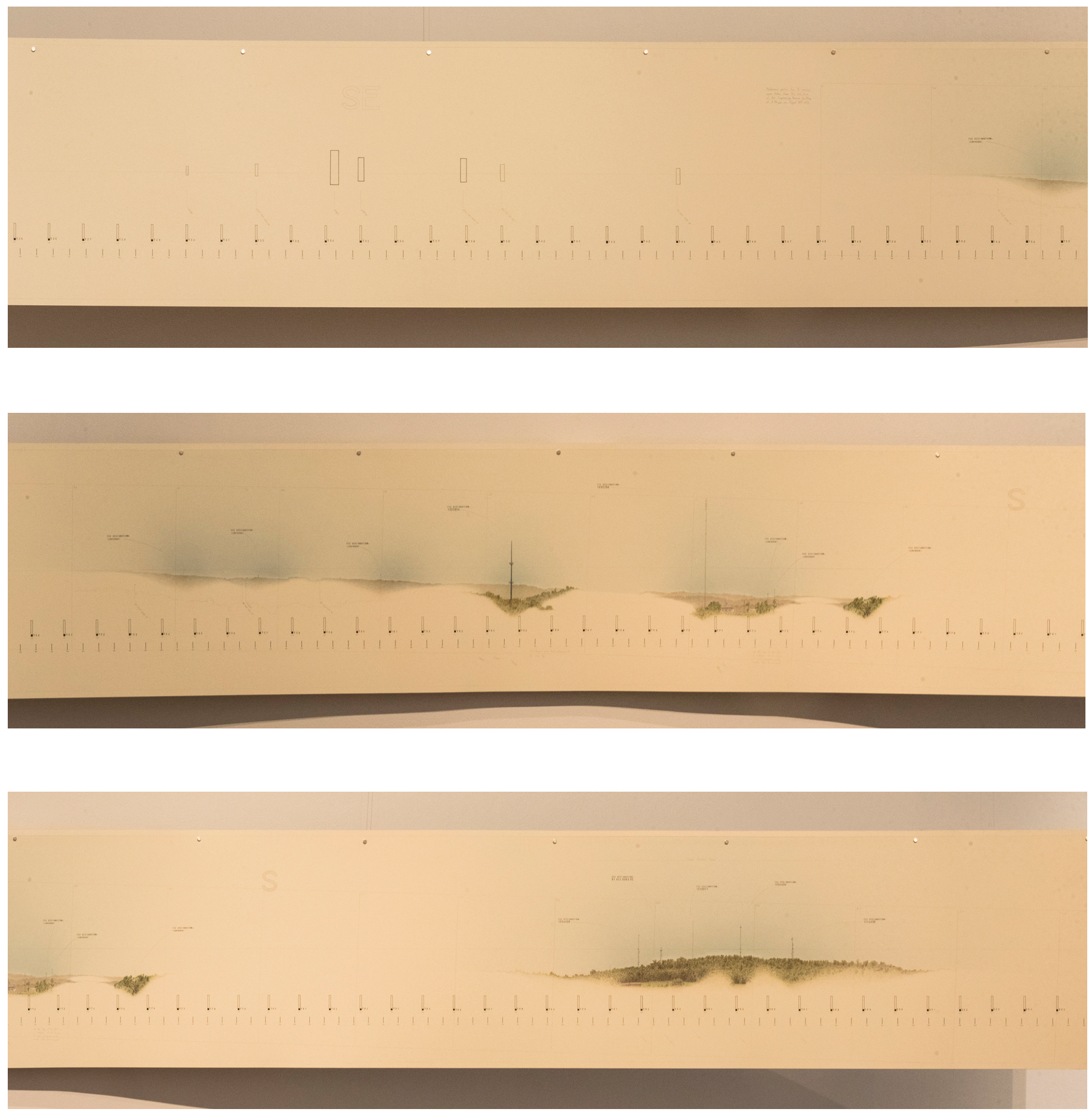

Figure 22. $290^{\circ}-22^{\circ}, 23^{\circ}-114^{\circ}, \& 115^{\circ}-207^{\circ}$

Stonehenge natural-colored rag paper, Rives BFK paper, Tyvek, poplar, neodymium magnets, ink, graphite, acrylic, watercolor, $\&$ colored pencil

$16 ”$ x 579"

2017 


\section{BIBLIOGRAPHY}

Becher, Bernd, and Hilla Becher. 1991. Pennsylvania coal mine tipples.

Becher, Bernd, and Hilla Becher. 2006. Grain elevators. Cambridge, Mass: MIT Press.

Bryant, David. 2004. "Typologies". Library Journal. 129 (11): 67.

Craig, Douglas B. "Radio, modern communication media and the technological sublime." Radio

Journal:International Studies in Broadcast \& Audio Media 6, no. 2 (2008): 129-43. doi:10.1386/rajo.6.2-3.129/1.

"Definition of sublime in English." Oxford Living Dictionaries. Accessed March 29, 2017.

https://en.oxforddictionaries.com/definition/sublime.

Hoffman, Katherine K. 2008. Botanical illustration: the challenge of combining science and art.

Holmes, Richard. The age of wonder: how the romantic generation discovered the beauty and terror of science. New York, NY: Pantheon Books/Vintage Books, 2010.

Kizer, George M. 2013. Digital microwave communication: engineering point-to-point microwave systems. http://public.eblib.com/choice/publicfullrecord.aspx?p=1188061.

Landy, Michael. "Nourishment." Paragon. Accessed April 10, 2017. http://paragonpress.co.uk/works/nourishment.

Lange, Susanne. 2007. Bernd and Hilla Becher: life and work. Cambridge, Mass: MIT Press.

Lehpamer, Harvey. 2002. Transmission systems design handbookfor wireless networks. Boston, MA: Artech House. http://public.eblib.com/choice/publicfullrecord.aspx?p=227594.

Lopez, Nicola. "Statement." Nicola Lopez -Bio. Accessed January 12, 2017.

http://nicolalopez.com/info_statement.htm.

Lubbock, Tom. "Dürer, Albrecht: The Large Turf (1503)." The Independent. January 17, 2008. Accessed March 18, 2017. https:/www.independent.co.uk/arts-entertainment/art/great-works/d-rer-albrecht-the-large-turf-1503770976.html.

Marx, Leo. The Machine in the garden: technology and the pastoral ideal in America. Leo Marx. New York: Oxford University Press, 1964.

"Mayflies of the Driftless Region." The Freshwater Blog. May 20, 2011. Accessed April 6, 2017. https://freshwaterblog.net/2011/05/20/mayflies-of-the-driftless-region/.

Meinig, D. W., and John Brinckerhoff Jackson. 1979. The Interpretation of ordinary landscapes: geographical essays. New York: Oxford University Press.

Moser, Stephanie. 2014. "Making Expert Knowledge through the Image: Connections between Antiquarian and Early Modern Scientific Illustration". Isis. 105 (1): 58-99.

Nickelsen, Kärin. "Draughtsmen, botanists and nature: constructing eighteenth-century botanical illustrations." Studies in History and Philosophy of Science Part C: Studies in History and Philosophy of Biological and Biomedical Sciences 37, no. 1 (2006): 1-25. doi:10.1016/j.shpsc.2005.12.001. 
Nickelsen, Kärin. Draughtsmen, botanists and nature: the construction of eighteenth-century botanical illustrations. Dordrecht: Springer, 2006.

"NOURISHMENT." Visit Visual Arts. Accessed March 10, 2017.

http://visualarts.britishcouncil.org/collection/portfolios/nourishment.

Nye, David E. 1994. American technological sublime. Cambridge, Mass: MIT Press.

"Ptolemy's World Map." The British Library - The British Library. Accessed March 12, 2017.

http://www.bl.uk/learning/timeline/item126360.html.

Pyle, Cynthia M. 2000. "Art as science: scientific illustration, 1490-1670 in drawing, woodcut and copper plate". Endeavour. 24 (2): 69-75.

Ralph Gilles: Automotive Design. Produced by Michael Pantaleo. Directed by Will Basanta and Clair Popkin. Performed by Ralph Gilles. Abstract: The Art of Design. February 2017. Accessed April 23, 2017.

https://www.netflix.com/watch/80093806?trackId=14170289\&tctx=0\%2C4\%2C2929fb28-98ef-4bbe-864cc06d476ac66d-29126085.

Schanilec, Gaylord, Clarke Garry, Gaylord Schanilec, and Greg Campbell. 2005. Mayflies of the driftless region: wood engravings. [Stockholm, Wis.]: Midnight Paper Sales.

Schanilec, Gaylord. "Notes on the Book." Gaylord Schanilec, fine printer and wood engraver. Accessed April 10, 2017. http://www.midnightpapersales.com/mayflies.html.

Smith, Pamela H. 2000. "Artists as scientists: nature and realism in early modern Europe". Endeavour. 24 (1): 1321.

Swaby, Rachel. "The Art of Disguising Cellphone Towers." Gizmodo. May 12, 2011. Accessed January 17, 2017. https://gizmodo.com/5801212/the-art-of-disguising-cellphone-towers.

"The Great Piece of Turf." National Gallery of Art - Albrecht Dürer, The Great Piece of Turf, 1503. Accessed April 21, 2017. https://www.nga.gov/exhibitions/2013/durer/fullscreen.shtm.

"Understanding Wireless Telephone Coverage Areas." Federal Communications Commission. October 26, 2016. Accessed April 12, 2017. https://www.fcc.gov/consumers/guides/understanding-wireless-telephone-coverage-areas.

"Uscellular_new.jpg." Digital image. My Education Discount. Accessed March 21, 2017.

http://www.myeducationdiscount.com/images/uscellular_new.jpg.

Wittgenstein, Ludwig. Philosophical investigations: the English text of the third edition. Translated by G. E. M. Anscombe. New York: Prentice Hall, 1968. 